\title{
Pulmonary hypertension phenotypes in patients with systemic sclerosis
}

\author{
Ashraful Haque ${ }^{1,2,3,6}$, David G. Kiely $\left(^{1,2}\right.$, Gabor Kovacs ${ }^{4,5}$, A.A. Roger Thompson $\mathbb{1}^{1,2}$ and \\ Robin Condliffe $\mathbb{1}^{1,2,6}$
}

${ }^{1}$ Sheffield Pulmonary Vascular Disease Unit, Royal Hallamshire Hospital, Sheffield, UK. ${ }^{2}$ Dept of Infection, Immunity and Cardiovascular Disease, University of Sheffield, Sheffield, UK. ${ }^{3}$ Dept of Rheumatology, Royal Hallamshire Hospital, Sheffield, UK. ${ }^{4}$ Medical University of Graz, Graz, Austria. ${ }^{5}$ Ludwig Boltzmann Institute for Lung Vascular Research, Graz, Austria. ${ }^{6}$ Both authors contributed equally.

Corresponding author: Robin Condliffe (robin.condliffe@nhs.net)

Shareable abstract (@ERSpublications)

Different forms of pulmonary hypertension can be present in patients with systemic sclerosis. In this article we review the epidemiology, diagnosis, outcomes and treatment of the spectrum of pulmonary vascular phenotypes associated with systemic sclerosis. https://bit.ly/3xUwrVB

Cite this article as: Haque A, Kiely DG, Kovacs G, et al. Pulmonary hypertension phenotypes in patients with systemic sclerosis. Eur Respir Rev 2021; 30: 210053 [DOI: 10.1183/16000617.0053-2021].

Copyright @The authors 2021

This version is distributed under the terms of the Creative Commons Attribution NonCommercial Licence 4.0. For commercial reproduction rights and permissions contact permissions@ersnet.org

Received: 28 Feb 2021 Accepted: 4 May 2021

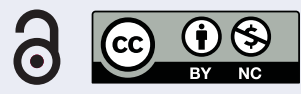

\section{Abstract}

Pulmonary hypertension (PH) commonly affects patients with systemic sclerosis (SSc) and is associated with significant morbidity and increased mortality. PH is a heterogenous condition and several different forms can be associated with SSc, including pulmonary arterial hypertension (PAH) resulting from a pulmonary arterial vasculopathy, $\mathrm{PH}$ due to left heart disease and $\mathrm{PH}$ due to interstitial lung disease. The incidence of pulmonary veno-occlusive disease is also increased. Accurate and early diagnosis to allow optimal treatment is, therefore, essential. Recent changes to diagnostic haemodynamic criteria at the 6th World Symposium on Pulmonary Hypertension have resulted in therapeutic uncertainty regarding patients with borderline pulmonary haemodynamics. Furthermore, the optimal pulmonary vascular resistance threshold for diagnosing $\mathrm{PAH}$ and the role of exercise in identifying early disease require further elucidation. In this article we review the epidemiology, diagnosis, outcomes and treatment of the spectrum of pulmonary vascular phenotypes associated with SSc.

\section{Introduction}

Systemic sclerosis (SSc) is a multisystem autoimmune disorder characterised by inflammation, excessive collagen deposition and fibrosis [1]. Limited cutaneous systemic sclerosis (LcSSc) is characterised by skin thickening distal to the elbows and knees, with or without facial and neck involvement, and the frequent presence of anti-centromere antibodies, while diffuse cutaneous systemic sclerosis (DcSSc) is characterised by proximal skin thickening and a predominance of anti-topoisomerase 1 (Scl-70) antibodies and anti-RNA polymerase III antibodies [2]. Earlier and more frequent organ involvement occurs in DcSSc [3]. A small proportion of patients may present with clinical features of SSc in the absence of skin thickening (SSc sine scleroderma).

Pulmonary hypertension (PH) describes a heterogenous group of conditions defined by an elevated mean pulmonary arterial pressure (mPAP). Five classification groups are described: Group 1: pulmonary arterial and/or hypoxia (PH-lung); Group 4: $\mathrm{PH}$ due to pulmonary artery obstructions; Group 5: PH with unclear and/or multifactorial mechanisms (figure 1) [5]. PAH is characterised by a progressive pulmonary arterial vasculopathy. Subsequent increased pulmonary vascular resistance (PVR) and pulmonary arterial pressure lead to increased right ventricular (RV) afterload with subsequent RV dysfunction, failure and premature death [6-8]. Despite the availability of specific therapies targeting three main pathways, PAH associated with SSc (SSc-PAH) is associated with a poor prognosis with 3-year survival of only 52\% [9]. Patients with SSc may also develop other forms of PH (SSc-PH), especially PH-LHD (SSc-PH-LHD) and PH-lung hypertension (PAH); Group 2: PH due to left heart disease (PH-LHD); Group 3: PH due to lung diseases 


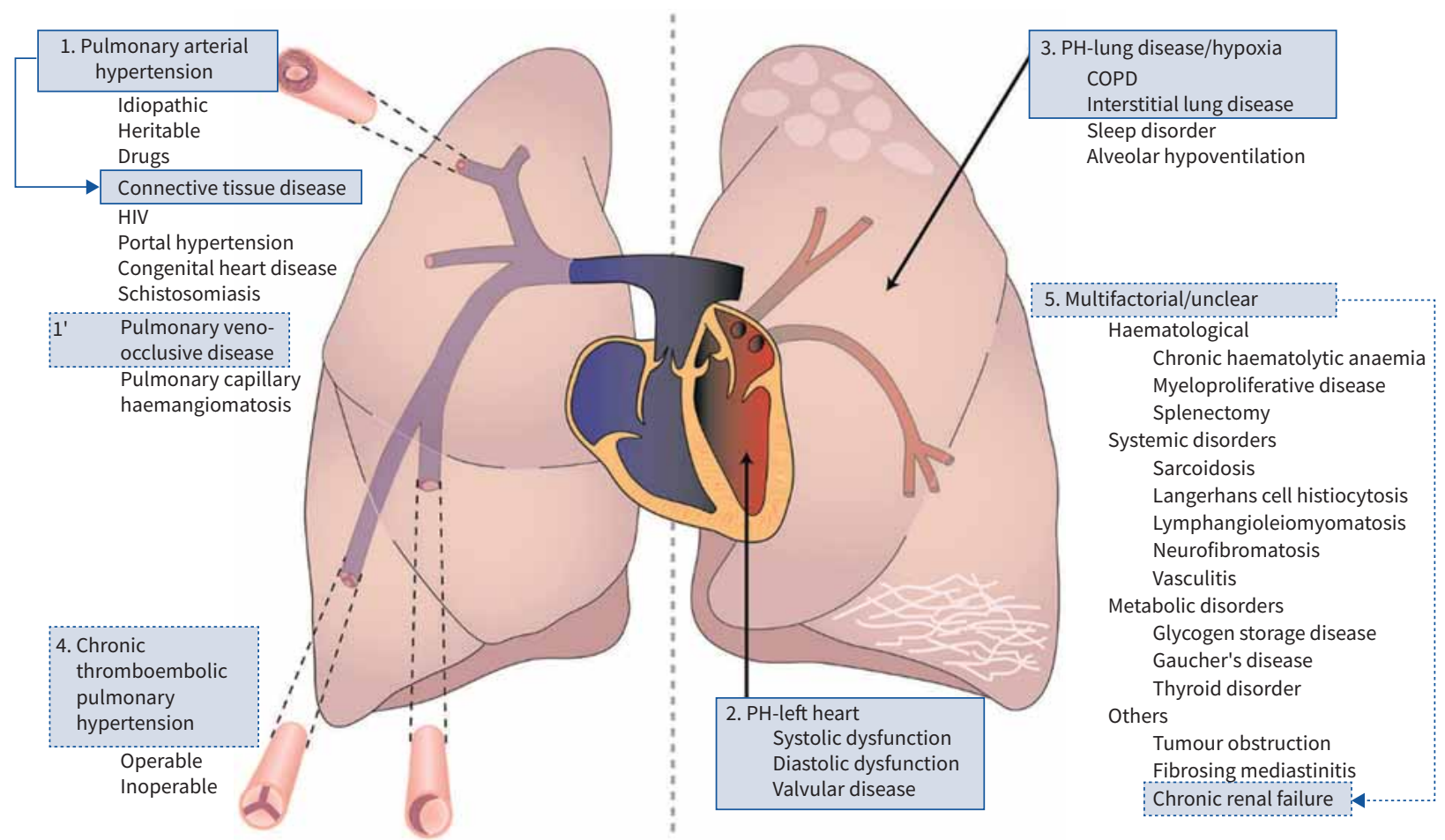

FIGURE 1 Potential pulmonary hypertension (PH) classification groups associated with systemic sclerosis. Patients may develop a pulmonary arterial vasculopathy (group 1, pulmonary arterial hypertension), may develop PH due to left heart disease (group 2) or PH due to lung disease (group 3; most commonly interstitial lung disease, although the incidence of combined fibrosis and emphysema is also increased). The incidence of pulmonary veno-occlusive disease (group $1^{\prime}$ ) also appears to be increased in systemic sclerosis. Chronic thromboembolic PH (group 4) should be excluded while patients with a previous scleroderma renal crisis who progress to end-stage chronic kidney disease may develop group 5 disease. Reproduced and modified from [4] with permission from the publisher.

(SSc-PH-lung). Pulmonary venous involvement may be relatively common in patients diagnosed with SSc-PAH while some patients may present with a predominant picture of pulmonary veno-occlusive disease (PVOD) [10-12]. Patients may also rarely present with group 4 disease, chronic thromboembolic pulmonary hypertension, as SSc is associated with an increased risk of venous thromboembolism [13].

Diagnostic criteria with regard to the threshold of mPAP used to define the presence of $\mathrm{PH}$, the use or non-use of a threshold for PVR to diagnose PAH, and the presence or absence of the entity of PH on exercise (PH-exercise) have changed over recent years (table 1). Furthermore, there are now a group of patients with elevated mPAP but normal PVR who are unclassifiable according to the most recent World Symposium on Pulmonary Hypertension (WSPH). Making the correct diagnosis regarding the form of SSc-PH is of critical importance in informing prognosis and guiding the most appropriate management strategy. Therefore, in this article we review the different PH phenotypes present in patients with SSc (table 2).

\section{Methods}

A PubMed systematic literature search was undertaken using the following search criteria:

((Systemic sclerosis) OR (Scleroderma) OR (Limited cutaneous systemic sclerosis) OR (Diffuse cutaneous systemic sclerosis)) AND ((Pulmonary hypertension) OR (Pulmonary arterial hypertension)) AND ((Exercise) OR (Borderline) OR (Interstitial lung disease) OR (ILD) OR (Diffusion capacity) OR (Left heart disease) OR (DLCO) OR (Transfer factor) OR (Phenotype)).

218 search results were all analysed for relevant information. Furthermore, a grey search of the manuscripts cited within these articles was undertaken together with the inclusion of key legacy papers.

\section{Changing definitions of $\mathrm{PH}$}

The first WSPH was organised by the World Health Organization (WHO) in 1973 in response to a European epidemic of appetite suppressant-induced PH [14]. It defined PH by a mPAP at right heart 
TABLE 1 Haemodynamic diagnostic criteria of the six World Symposia on Pulmonary Hypertension (WSPH)

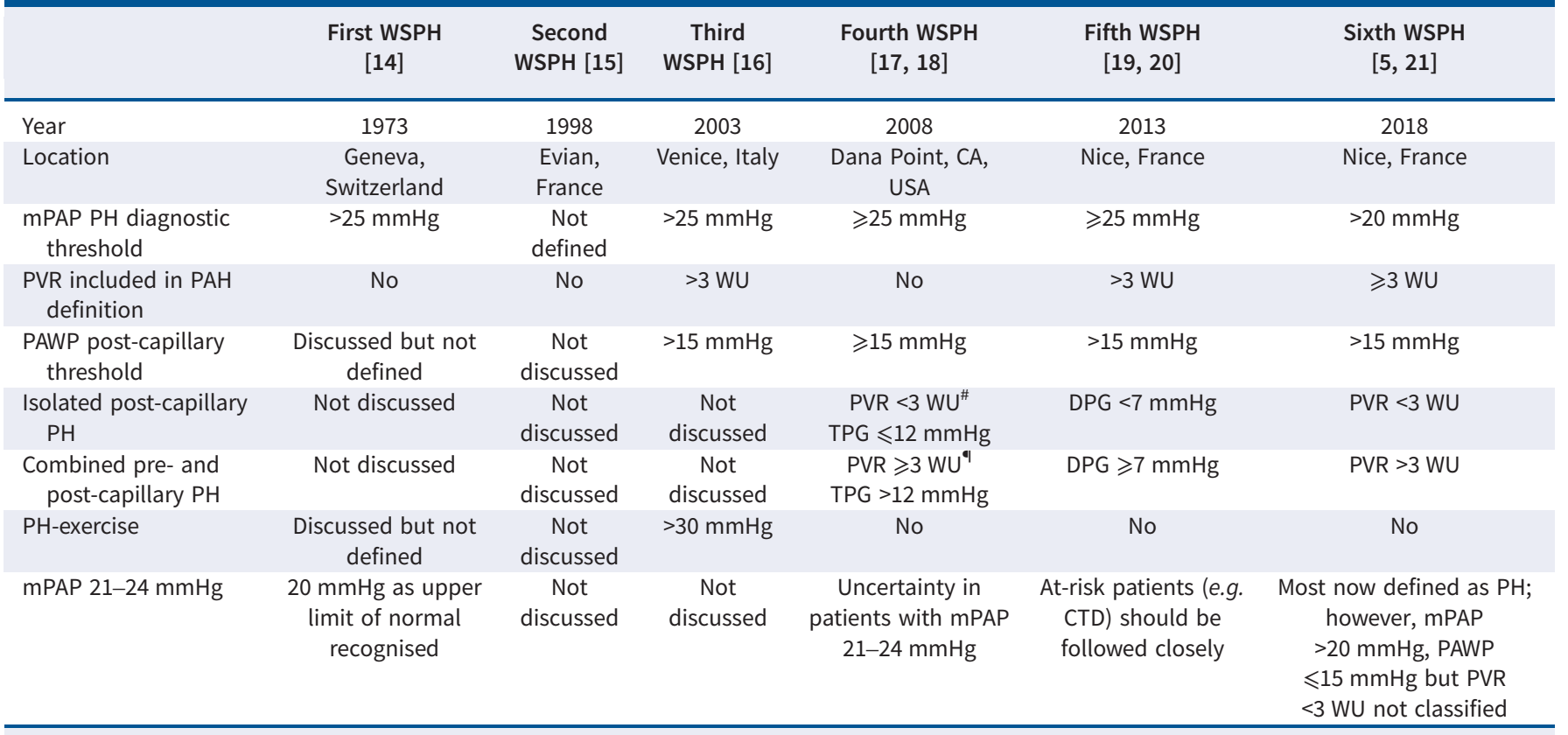

mPAP: mean pulmonary arterial pressure; PH: pulmonary hypertension; PVR: pulmonary vascular resistance; PAH: pulmonary arterial hypertension; PAWP: pulmonary arterial wedge pressure; WU: Wood Units; TPG: transpulmonary gradient; DPG: diastolic pulmonary gradient; CTD: connective tissue disease. ": termed "diastolic heart failure"; ": termed "pre-capillary PH and diastolic dysfunction".

catheterisation (RHC) $>25 \mathrm{mmHg}$ (table 1) [14]. This haemodynamic definition was derived from the recommendation of a previous WHO report on cor pulmonale, published in 1961 [22]. The diagnostic threshold of $25 \mathrm{mmHg}$ would remain until the sixth WSPH in 2018 where it was proposed that the threshold be reduced to $>20 \mathrm{mmHg}$ [5]. This change in definition was suggested following a systematic

TABLE 2 Systemic sclerosis (SSC)-pulmonary hypertension (PH) phenotypes

\begin{tabular}{|c|c|}
\hline SSc-PAH: post-6th WSPH & $\mathrm{mPAP} \geqslant 20 \mathrm{mmHg}$, PAWP $\leqslant 15 \mathrm{mmHg}, \mathrm{PVR} \geqslant 3 \mathrm{WU}$ \\
\hline SSc-PAH: pre-6th WSPH & $m P A P \geqslant 25 \mathrm{mmHg}$, PAWP $\leqslant 15 \mathrm{mmHg}, \mathrm{PVR}>3 \mathrm{WU}$ \\
\hline $\begin{array}{l}\text { SSc: } \mathrm{mPAP}>20 \mathrm{mmHg} \\
\text { PVR }<3 \mathrm{WU}\end{array}$ & $\begin{array}{l}\text { A group of patients with elevated mPAP who do not fulfil current PH diagnostic } \\
\text { criteria of pre- or post-capillary PH }\end{array}$ \\
\hline SSc-BoPH & $\begin{array}{l}\text { Term used in the literature to describe patients with borderline haemodynamics } \\
\text { (mPAP } 21-24 \mathrm{mmHg} \text { ) prior to the current 6th WSPH PH definition }\end{array}$ \\
\hline SSc-PH-exercise & $\begin{array}{l}\text { Previously, resting mPAP }<25 \mathrm{mmHg} \text { but } \mathrm{mPAP}>30 \mathrm{mmHg} \text { on exercise; more } \\
\text { recent definition (not included in 6th WSPH) suggested as resting mPAP } \\
<25 \mathrm{mmHg} \text { but mPAP }>30 \mathrm{mmHg} \text { and TPR }>3 \mathrm{WU} \text { on exercise }\end{array}$ \\
\hline SSC-PVOD & $\begin{array}{l}\text { Meets haemodynamic criteria for PAH but radiological and clinical features of } \\
\text { PVOD }\end{array}$ \\
\hline SSC-PH-LHD & $m P A P \geqslant 20 \mathrm{mmHg}$, PAWP $>15 \mathrm{mmHg}$ \\
\hline SSc-IpcPH & $m P A P \geqslant 20 \mathrm{mmHg}$, PAWP $>15 \mathrm{mmHg}, \mathrm{PVR}<3 \mathrm{WU}$ \\
\hline SSc-CpcPH & $\mathrm{mPAP} \geqslant 20 \mathrm{mmHg}, \mathrm{PAWP}>15 \mathrm{mmHg}, \mathrm{PVR} \geqslant 3 \mathrm{WU}$ \\
\hline SSc-PH-HFpEF & SSc-PH-LHD due to heart failure with preserved ejection fraction \\
\hline SSC-PH-HFrEF & SSc-PH-LHD due to heart failure with reduced ejection fraction \\
\hline SSC-PH-ILD & $\begin{array}{l}\mathrm{mPAP} \geqslant 20 \mathrm{mmHg}, \text { PAWP } \leqslant 15 \mathrm{mmHg}, \mathrm{PVR} \geqslant 3 \mathrm{WU} \text { in the presence of significant } \\
\text { ILD (often defined as HRCT showing }>20 \% \text { fibrotic lung involvement and/or } \\
\text { FVC }<70 \% \text { predicted) }\end{array}$ \\
\hline \multicolumn{2}{|c|}{$\begin{array}{l}\text { PAH: pulmonary arterial hypertension; WSPH: World Symposium on Pulmonary Hypertension; mPAP: mean } \\
\text { pulmonary arterial pressure; PVR: pulmonary vascular resistance; WU: Wood Units; BoPH: borderline PH; PVOD: } \\
\text { pulmonary veno-occlusive disease; LHD: left heart disease; IpCPH: isolated post-capillary PH; CPCPH: combined } \\
\text { pre- and post-capillary PH; HFpEF: heart failure with preserved ejection fraction; HFrEF: heart failure with } \\
\text { reduced ejection fraction; ILD: interstitial lung disease; PAWP: pulmonary arterial wedge pressure; TPR: total } \\
\text { pulmonary resistance; HRCT: high-resolution computed tomography; FVC: forced vital capacity. }\end{array}$} \\
\hline
\end{tabular}


review by Kovacs et al. [23] which demonstrated that the mean mPAP within the healthy population was $14.0 \pm 3.3 \mathrm{mmHg}$. In addition, MARON et al. [24] reviewed RHC data from 21727 patients in the US Veterans healthcare system and observed increased mortality in patients with a mPAP 19-24 mmHg compared with $<19 \mathrm{mmHg}$. Furthermore, a meta-analysis of 16482 patients performed by KoLTe et al. [25] also identified increased mortality in patients with $\mathrm{mPAP}>19 \mathrm{mmHg}$. It is interesting to note that although the 1961 report proposed a threshold of $25 \mathrm{mmHg}$, it also commented that the upper limit of normal for mPAP was $15 \mathrm{mmHg}$ [22]. Furthermore, the first WSPH also stated that the mPAP at rest "never" exceeded $20 \mathrm{mmHg}$ in healthy individuals [14]. The uncertain nature of patients with mPAP 21-24 mmHg had been recognised at the fourth and fifth World Symposia, but there were deemed to be insufficient data to introduce a formal definition of "borderline $\mathrm{PH}$ " $[18,19]$.

The effects of exercise on mPAP were discussed at the first WSPH, but were not included in diagnostic criteria [13]. By the third WSPH, a diagnostic threshold of mPAP $>30 \mathrm{mmHg}$ for the diagnosis of PH-exercise had been introduced [17, 26]. PH-exercise was, however, dropped from the diagnostic criteria in the fourth WSPH in 2008 as it was appreciated that mPAP may frequently increase $>30 \mathrm{mmHg}$ on exercise in normal individuals, especially those aged $>50$ years [17].

PVR was incorporated into the definition of PAH at the third WSPH using a threshold of $>3$ Wood Units (WU) [27]. Its inclusion in the definition aimed to prevent patients with flow-related increases in mPAP being diagnosed with PAH. Although it was temporarily absent from the fourth WSPH, it was reinserted into the diagnostic criteria for PAH at the fifth WSPH, albeit with the slight change of including patients with a PVR $\geqslant 3$ WU (as opposed to $>3$ WU) [19].

Left atrial pressure, most commonly assessed by the pulmonary arterial wedge pressure (PAWP), was introduced in the third WSPH to differentiate between pre-capillary (PAWP $\leqslant 15 \mathrm{mmHg}$ ) and post-capillary PH (PAWP >15 mmHg) [16].

\section{Summary}

Haemodynamic criteria for different forms of $\mathrm{PH}$ have changed over recent decades. The most recent WSPH defines pre-capillary PH as mPAP $>20 \mathrm{mmHg}$, PAWP $\leqslant 15 \mathrm{mmHg}$ and PVR $\geqslant 3$ WU.

\section{SSc-PAH}

Estimates of the prevalence of PAH within the SSc population range between $6.4 \%$ and 9\% [27, 28]. The incidence of SSc-PAH in patients with LcSSc and DcSSc is 1.25 and 0.4 cases per 100 patient-years, respectively [29]. Meta-analysis involving 3818 patients with RHC-confirmed PH identified PAH as the most common form of $\mathrm{PH}$ seen in SSc, comprising 63\% of RHC-confirmed cases [27]. There may, however, be ascertainment bias in these data due to patients with other forms of PH being less likely to undergo RHC. Historically, SSc-PAH was associated with a poor prognosis with a 3-year survival of $30 \%$ [30]. Mortality remains high despite the availability of PAH-specific therapy. Lefèvre et al. [9] observed 1 - and 3 -year survival rates of $81 \%$ and $52 \%$, respectively, in a meta-analysis.

Several studies have demonstrated that, despite having less severe pulmonary haemodynamics, survival of patients with SSc-PAH is worse than with idiopathic PAH (IPAH) [31-37]. There are several possible explanations for this including differences in patient characteristics, the underlying pulmonary arterial vasculopathy, and the ability of the RV to compensate for increased afterload.

\section{Patient characteristics}

When compared with IPAH, patients with SSc-PAH are older with a lower coefficient for diffusing capacity of the lung for carbon monoxide $\left(D_{\mathrm{LCO}}\right)$. In a multivariate analysis of 375 IPAH and SSc-PAH patients, Ramugg et al. [37] identified that higher age and lower $D_{\text {LCO }}$ were independent prognostic markers. The lower $D_{\text {LCO }}$ may reflect increased alveolar-capillary block due to overt or covert interstitial lung disease (ILD), reduced capillary blood volume related to the nature of the pulmonary vasculopathy or a component of PVOD. The multisystem nature of SSc, with involvement not only of the lungs and heart, but also the skin, gastrointestinal tract and kidneys, likely also impacts survival [38, 39].

\section{Vasculopathy}

OverbeEK et al. [12] demonstrated intimal fibrosis in histological specimens from all eight patients they studied with SSc-PAH compared with only three out of 11 patients with IPAH. Plexiform lesions were much less common than in patients with IPAH. Similarly, Dorfmüller et al. [11] observed marked muscular artery intimal fibrosis in four out of four SSc-PAH patients in contrast with only four out of 29 
patients with IPAH. In addition to differences in pulmonary arterial histology, there may also be an increased frequency of pulmonary venous lesions in SSc-PAH (see PVOD section) [40].

\section{Right ventricle}

OverbeEK et al. [41] demonstrated poorer RV contractility in 13 patients with SSc-PAH compared with 17 IPAH patients. Similarly, TEDFORD et al. [42] observed worse RV contractility and coupling of RV contractility with afterload in seven SSc-PAH patients compared with five IPAH patients. MathAi et al. [43] found N-terminal pro-B-type natriuretic peptide (NT-proBNP) levels in 55 SSc-PAH patients to be significantly higher than in 43 IPAH patients, despite the IPAH group having more severe $\mathrm{PH}$. Furthermore, although OvERBEeK et al. [41] found no difference in the extent of interstitial fibrosis in the RVs obtained at autopsy of five SSc-PAH and nine IPAH patients, there was an increased inflammatory myocardial infiltrate in the SSc-PAH group. Conversely, Hsu et al. [44] observed increased interstitial fibrosis in RV endomyocardial biopsies obtained from 11 SSc-PAH patients when compared with seven IPAH patients and six SSc patients without PH. Interestingly, when compared with healthy controls, sarcomere function (as assessed by the maximum calcium-activated force) was significantly lower in SSc-PAH but significantly higher in IPAH. Sarcomere function in SSc patients without PH was intermediate between the controls and SSc-PAH.

\section{Medical therapy in SSC-PAH}

Current therapies for PAH target three main pathways: nitric oxide, endothelin-1 and prostacyclin [45, 46]. A number of randomised controlled trials (RCTs) have published data on outcomes in patients with connective tissue disease (CTD), the majority of whom had SSc (table 3) [63]. With the exception of an unblinded RCT of epoprostenol, short-term monotherapy RCTs have tended to report lower response to therapy in patients with CTD associated PAH (CTD-PAH) [64, 65]. However, newer data from longer studies where the majority of patients have received combination therapy have challenged these findings $[54,56,61]$.

\section{Screening}

Humbert et al. [66] observed milder haemodynamics and superior survival in a cohort of SSc patients identified in a screening programme as compared to presenting symptomatically. Although lead-time bias cannot be excluded as a cause of the superior survival, subsequent RCTs of PAH therapies have demonstrated larger treatment response of patients in functional class (FC) II compared with FC III [67]. There is, therefore, a good rationale for screening asymptomatic SSc patients to enable earlier treatment [68]. Coghlan et al. [69] compared the multi-modality 2-step DETECT algorithm with the European Respiratory Society/European Society of Cardiology (ERS/ESC) approach of echocardiography alone and observed sensitivity/specificity for identifying PAH (mPAP $\geqslant 25 \mathrm{mmHg}$ and PAWP $\leqslant 15 \mathrm{mmHg}$ ) of 96\%/ 48\% and 71\%/69\%, respectively. The Australian Scleroderma Interest Group (ASIG) studied an approach using pulmonary function tests and NT-proBNP and reported sensitivity/specificity for identifying PAH of 94\%/55\% compared with 95\%/32\% for the ERS/ESC approach [70]. HAO et al. [71] compared all three approaches in 73 patients and observed that although the DETECT and ASIG approaches performed similarly, the ASIG algorithm reduced the need for RHC without missing any cases of PAH. A direct comparison of approaches is, however, difficult due to inclusion criteria used in different studies [72].

Although no difference in the incidence of PAH was identified when comparing the DETECT algorithm

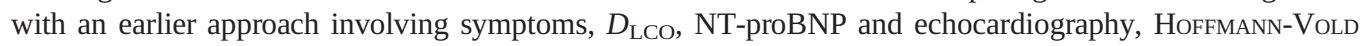
et al. [73] observed that DETECT identified a significantly higher number of patients with mPAP 21-24 mmHg (31\% versus 17\%).

\section{Summary}

Survival in SSc-PAH is worse than in IPAH which may be related to a number of factors including the multisystem nature of SSc and the capacity of the RV to accommodate increased afterload. Data from RCTs of combination therapies with combined morbidity/mortality end-points have, however, reported equivalent outcomes to those seen in IPAH. Patients with SSc-PAH should therefore receive timely dual and triple combination therapy. Asymptomatic SSc patients should be entered into screening programmes.

\section{Impact of the sixth WSPH definition}

Two studies investigating the effect of lowering the mPAP diagnostic threshold from $\geqslant 25$ to $>20 \mathrm{mmHg}$ in patients with SSc have been published. JAAFAR et al. [74] performed a retrospective, single centre analysis of 268 SSc patients who had undergone RHC [75]. Seven (5\%) out of 131 SSc patients without PH according to the old definition were re-classified to either pre-capillary PH (PAH: n=1; PH-lung: $n=3$ ) or post-capillary $\mathrm{PH}(\mathrm{n}=3)$ [74]. In those with mPAP 21-24 mmHg but without significant lung or left heart 
TABLE 3 Key randomised controlled trials and sub-group analyses in systemic sclerosis (SSc)-pulmonary arterial hypertension (PAH)

$\begin{array}{lccccc}\text { Study [ref.] Drug } & \begin{array}{c}\text { Study } \\ \text { length }\end{array} & \begin{array}{c}\text { CTD } \\ \text { patients } \\ n\end{array} & \text { CTD type } & \begin{array}{c}\text { Outcome in overall/comparator } \\ \text { study }\end{array} & \text { Outcomes in CTD sub-group } \\ & & n\end{array}$

\begin{tabular}{|c|c|c|c|c|c|c|}
\hline $\begin{array}{l}\text { Nitric oxide } \\
\text { pathway }\end{array}$ & & & & & & \\
\hline $\begin{array}{l}\text { SUPER-1 } \\
{[47,48]}\end{array}$ & $\begin{array}{l}\text { Sildenafil } 20 \mathrm{mg}, \\
40 \mathrm{mg}, 80 \mathrm{mg} \text { three } \\
\text { times daily }\end{array}$ & 12 weeks & 84 & $\begin{array}{l}45 \% \text { SSc, } \\
23 \% \text { SLE, } \\
32 \% \text { other }\end{array}$ & 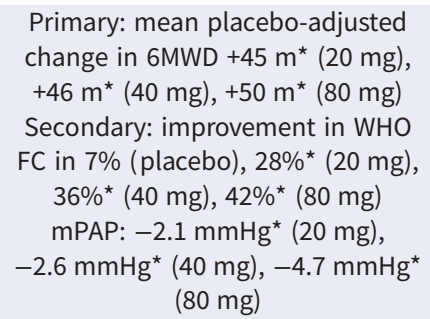 & $\begin{array}{c}\text { Primary: } 6 \mathrm{MWD}-13 \mathrm{~m} \text { (placebo), } \\
+42 \mathrm{~m}^{\star}(20 \mathrm{mg}),+36 \mathrm{~m} \text { Ns }(40 \mathrm{mg}) \\
+15 \mathrm{~m} \text { Ns }(80 \mathrm{mg}) \\
\text { Secondary: improvement in WHO } \\
\text { FC in } 5 \% \text { (placebo), } 29 \%^{*}(20 \mathrm{mg}), \\
40 \% \%^{\star}(40 \mathrm{mg}), 42 \%^{*}(80 \mathrm{mg}) \\
\text { mPAP: }-4.6 \mathrm{mmHg}{ }^{*}(20 \mathrm{mg}), \\
-2.8 \mathrm{mmHg} \text { Ns }(40 \mathrm{mg}),-3.2 \mathrm{mmHg} \\
\text { Ns ( } 80 \mathrm{mg})\end{array}$ \\
\hline $\begin{array}{l}\text { PHIRST-1 } \\
{[49,50]}\end{array}$ & $\begin{array}{l}\text { Tadalafil } 2.5 \mathrm{mg}- \\
40 \text { mg once daily } \\
53 \% \text { background } \\
\text { Bosentan }\end{array}$ & 16 weeks & 56 & Unknown & $\begin{array}{l}\text { Primary: mean placebo-adjusted } \\
\text { change in } 6 \mathrm{MWD}+27 \mathrm{~m}^{\star}(20 \mathrm{mg}) \\
+33 \mathrm{~m}^{\star}(40 \mathrm{mg}) \\
\text { Secondary: no overall significant } \\
\text { effect on WHO FC } \\
\text { Time to clinical worsening } \\
\text { improved in } 40 \mathrm{mg} \text { dose* }\end{array}$ & $\begin{array}{l}\text { Primary: exact distances not } \\
\text { specified but comparable to IPAH } \\
\text { Secondary: higher proportion } \\
\text { worsened and lower proportion } \\
\text { improved WHO FC in CTD-PAH cf } \\
\text { IPAH } \\
\text { Higher rate of clinical worsening in } \\
40 \mathrm{mg} \text { dose (11\% versus } 4 \% \text { IPAH) }\end{array}$ \\
\hline $\begin{array}{l}\text { PATENT-1 } \\
{[51,52]}\end{array}$ & $\begin{array}{l}\text { Riociguat up to } \\
2.5 \text { mg three times } \\
\text { daily } \\
44 \% \text { background } \\
\text { ERA } \\
6 \% \text { background } \\
\text { prostanoid }\end{array}$ & 12 weeks & 111 & $\begin{array}{l}59 \% \text { SSc, } \\
16 \% \text { SLE, } \\
25 \% \text { other }\end{array}$ & $\begin{array}{l}\text { Primary: treatment arm } 6 \mathrm{MWD} \\
+30 \mathrm{~m} \text { versus placebo }-6 \mathrm{~m} \text { (mean } \\
\text { placebo-adjusted change }+36 \mathrm{~m}^{\star} \text { ) } \\
\text { Secondary: placebo: improvement } \\
\text { in WHO FC in } 14 \% \text { and worsening } \\
\text { in } 14 \% \text {; treatment: improvement in } \\
\text { WHO FC in } 21 \% \text { and worsening in } \\
4 \%{ }^{*} \\
\text { PVR: }-9 \text { dyn } \cdot \mathrm{s}^{-5}{ }^{-5}(\mathrm{placebo}) \\
\text { versus }-223 \mathrm{dyn} \cdot \mathrm{s} \cdot \mathrm{cm}^{-5} \\
\text { (treatment) } \\
\text { NT-proBNP: }+232 \mathrm{pg} \cdot \mathrm{mL}^{-1} \\
\text { (placebo) versus }-198 \mathrm{pg} \cdot \mathrm{mL}^{-1} \\
\text { (treatment) }{ }^{*}\end{array}$ & $\begin{array}{l}\text { Primary: SSc treatment arm 6MWD } \\
+4 \text { m versus placebo }-37 \mathrm{~m}^{\star} \\
\text { Secondary: SSc placebo: } \\
\text { improvement in WHO FC in } 13 \% \\
\text { and worsening in } 27 \% \text {; treatment: } \\
\text { improvement in WHO FC in } 16 \% \\
\text { and worsening in } 2 \%{ }^{*} \\
\text { PVR: }-79 \mathrm{dyn} \cdot \mathrm{s} \cdot \mathrm{cm}^{-5} \text { (placebo) } \\
\text { versus }-132 \mathrm{dyn} \cdot \mathrm{s} \cdot \mathrm{cm}^{-5} \text { (treatment) } \\
\text { NT-proBNP: }+142 \mathrm{pg} \cdot \mathrm{mL}^{-1} \text { (placebo) } \\
\text { versus }+98 \mathrm{pg} \cdot \mathrm{mL}^{-1} \text { (treatment) }\end{array}$ \\
\hline \multicolumn{7}{|l|}{ ERA-1 } \\
\hline $\begin{array}{l}\text { BREATHE-1 } \\
\text { [53] }\end{array}$ & $\begin{array}{c}\text { Bosentan } \\
\text { 125-250 mg twice } \\
\text { daily }\end{array}$ & 16 weeks & 63 & $\begin{array}{l}75 \% \text { SSc, } \\
25 \% \text { SLE }\end{array}$ & $\begin{array}{l}\text { IPAH treatment arm } 6 \mathrm{MWD}+46 \mathrm{~m} \\
\text { versus placebo }-5 \mathrm{~m}^{\star}\end{array}$ & $\begin{array}{c}\text { SSc treatment arm } 6 M W D+3 m \\
\text { versus placebo }-40 m\end{array}$ \\
\hline $\begin{array}{l}\text { AMBITION } \\
{[54,55]}\end{array}$ & $\begin{array}{l}\text { Ambrisentan } 10 \mathrm{mg} \\
\text { and/or Tadalafil } \\
40 \mathrm{mg} \text { once daily }\end{array}$ & $\begin{array}{c}\text { Mean } \\
74 \text { weeks }\end{array}$ & 187 & $\begin{array}{l}63 \% \text { SSc, } \\
12 \% \text { MCTD, } \\
9 \% \text { SLE }\end{array}$ & $\begin{array}{l}50 \% \text { risk reduction of combined } \\
\text { morbidity/mortality end-point }{ }^{\star}\end{array}$ & $\begin{array}{l}56 \% \text { risk reduction of combined } \\
\text { morbidity/mortality end-point }{ }^{\star}\end{array}$ \\
\hline $\begin{array}{l}\text { SERAPHIN } \\
\text { [56] }\end{array}$ & $\begin{array}{l}\text { Macitentan } 10 \mathrm{mg} \\
\text { once daily } \\
64 \% \text { on background } \\
\text { PAH therapy }\end{array}$ & $\begin{array}{c}\text { Mean } \\
115 \text { weeks }\end{array}$ & 224 & $\begin{array}{l}63 \% \text { SSc, } \\
12 \% \text { MCTD, } \\
9 \% \text { SLE }\end{array}$ & $\begin{array}{l}50 \% \text { risk reduction of combined } \\
\text { morbidity/mortality end-point }{ }^{\star}\end{array}$ & $\begin{array}{l}56 \% \text { risk reduction of combined } \\
\text { morbidity/mortality end-point }{ }^{*}\end{array}$ \\
\hline \multicolumn{7}{|l|}{ Prostanoid } \\
\hline$[57,58]$ & $\begin{array}{l}\text { Intravenous } \\
\text { epoprostenol }\end{array}$ & 12 weeks & 111 & $100 \%$ SSc & $\begin{array}{c}\text { IPAH study treatment arm }+47 \mathrm{~m} \\
\text { versus conventional therapy } \\
-66 \mathrm{~m}^{\star} \\
\text { Secondary: mPAP mean } \\
\text { placebo-adjusted difference } \\
-6.7 \mathrm{mmHg}{ }^{\star} \\
\text { PVR mean placebo-adjusted } \\
\text { difference }-4.9 \mathrm{WU}^{\star}\end{array}$ & $\begin{array}{c}\text { Primary: treatment arm 6MWD } \\
+46 \mathrm{~m} \text { versus conventional therapy } \\
-48 \mathrm{~m}^{\star} \\
\text { Secondary: } \mathrm{mPAP} \text { mean } \\
\text { placebo-adjusted difference } \\
-6 \mathrm{mmHg}^{*} \\
\text { PVR mean placebo-adjusted } \\
\text { difference }-5.5 \mathrm{WU}^{\star}\end{array}$ \\
\hline$[59,60]$ & $\begin{array}{l}\text { Subcutaneous } \\
\text { treprostinil } \\
\text { Background therapy } \\
\text { unclear }\end{array}$ & 12 weeks & 90 & $\begin{array}{l}50 \% \text { SSc, } \\
28 \% \text { SLE, } \\
19 \% \text { MCTD }\end{array}$ & $\begin{array}{c}\text { Primary: treatment arm 6MWD } \\
\text { median }+10 \mathrm{~m} \text { versus placebo } \\
+0 \mathrm{~m}^{\star} \\
\text { Secondary: } \mathrm{mPAP}-2.3 \mathrm{mmHg}{ }^{\star} \text {, } \\
\text { PVRi }-3.5 \mathrm{WU} \cdot \mathrm{m}^{-2 \star}\end{array}$ & $\begin{array}{c}\text { Primary: treatment arm } 6 \mathrm{MWD} \\
+24 \mathrm{~m} \text { versus placebo }+3 \mathrm{~m} \\
\text { Secondary: } \mathrm{mPAP}-3 \mathrm{mmHg} \text {, PVRi } \\
-4 \mathrm{WU} \cdot \mathrm{m}^{-2 \star}\end{array}$ \\
\hline
\end{tabular}




\begin{tabular}{|c|c|c|c|c|c|c|}
\hline Study [ref.] & Drug & $\begin{array}{l}\text { Study } \\
\text { length }\end{array}$ & $\begin{array}{c}\text { CTD } \\
\text { patients } \\
n\end{array}$ & CTD type & $\begin{array}{c}\text { Outcome in overall/comparator } \\
\text { study }\end{array}$ & Outcomes in CTD sub-group \\
\hline $\begin{array}{l}\text { GRIPHON } \\
{[61,62]}\end{array}$ & $\begin{array}{c}\text { Selexipag } 200- \\
1600 \mu \mathrm{g} \text { twice daily } \\
80 \% \text { on background } \\
\text { PAH therapy }\end{array}$ & $\begin{array}{c}\text { Mean } \\
70 \text { weeks }\end{array}$ & 334 & $\begin{array}{l}51 \% \text { SSc, } \\
25 \% \text { SLE, } \\
25 \% \text { MCTD/ } \\
\text { other }\end{array}$ & $\begin{array}{l}40 \% \text { risk reduction of combined } \\
\text { morbidity/mortality end-point }{ }^{\star}\end{array}$ & $\begin{array}{l}41 \% \text { risk reduction of combined } \\
\text { morbidity/mortality end-point* }\end{array}$ \\
\hline
\end{tabular}

CTD: connective tissue disease; ERA-1: endothelin receptor antagonist-1; SLE: systemic lupus erythematosus; 6MWD: 6-min walk distance; WHO FC: World Health Organization functional class; mPAP: mean pulmonary arterial pressure; Ns: nonsignificant; IPAH: idiopathic pulmonary arterial hypertension; PVR: pulmonary vascular resistance; NT-proBNP: N-terminal pro-brain natriuretic peptide; MCTD: mixed connective tissue disease; PVRi: PVR index; WU: Wood Units. *: $p<0.05$.

disease $(n=28)$, a single patient (4\% of the $21-24 \mathrm{mmHg}$ group, $1 \%$ of the original no $\mathrm{PH}$ group) was reclassified as having PAH [74]. The authors also reanalysed 244 patients from the original DETECT cohort [69] and found that four (11\%) out of 36 patients with mPAP 21-24 mmHg were reclassified as having PAH. XANTHOULI et al. [76] subsequently studied 284 SSc patients, 146 (49\%) of whom had a mPAP $\leqslant 20 \mathrm{mmHg}$ and 55 (19\%) had a mPAP of $21-24 \mathrm{mmHg}$. Only four patients (7\% of the 21-24 mmHg group, $2 \%$ of the original no $\mathrm{PH}$ group) were reclassified with $\mathrm{PAH}$ [76]. The authors of both studies concluded that the new diagnostic criteria (with a change only to the mPAP threshold) had limited impact on the diagnosis of SSc-PAH.

\section{Summary}

Changes to the haemodynamic diagnosis of pre-capillary PH proposed at the sixth WSPH have only a modest effect on the number of patients diagnosed with SSc-PAH.

\section{Elevated mPAP with PVR $<3$ WU}

A proportion of SSc patients with normal PAWP who have preserved/mildly impaired cardiac outputs may have a mPAP $>20 \mathrm{mmHg}$ but a PVR $<3 \mathrm{WU}$. For example, a SSc patient with a mPAP of $26 \mathrm{mmHg}$, PAWP $12 \mathrm{mmHg}$ and a cardiac output of $5 \mathrm{~L} \cdot \mathrm{min}^{-1}$ has a PVR of $(26-12) / 5=2.8 \mathrm{WU}$ and hence cannot be assigned a PH category. This occurrence will be made more common by the change in diagnostic threshold for mPAP from $\geqslant 25 \mathrm{mmHg}$ to $>20 \mathrm{mmHg}$. In the study by JAAFAR et al. [74] discussed above, the use of a PVR threshold of $2 \mathrm{WU}$ instead of $3 \mathrm{WU}$ would have resulted in an increase from one to nine PAH re-diagnoses (32\% of all patients with mPAP 21-24 mmHg). Similarly, in the study of Xanthoul et al. [76], the number of re-diagnoses would have increased from four to 28 (51\% of patients with mPAP 21-24 mmHg). The use of a lower PVR threshold for the diagnosis of PAH is supported by several studies.

Xanthouli et al. [76] observed that the 28 patients with mPAP 21-24 mmHg but PVR $\geqslant 2$ WU had lower 6-min walk distance (6MWD) and TAPSE (tricuspid annulus systolic excursion) and worse survival than patients with a PVR $<2$ WU. KovAcs et al. [77] found the mean PVR in 222 healthy volunteers in the literature to range from $0.77 \pm 0.3 \mathrm{WU}$ in people aged $<24$ years to $1.13 \pm 0.5 \mathrm{WU}$ in people aged $\geqslant 70$ years. MARon et al. [78] retrieved RHC data from 40082 patients in the US Veterans healthcare system (many with heart failure and/or COPD). In those patients with a mPAP $\geqslant 19 \mathrm{mmHg}$ and PAWP $\leqslant 15 \mathrm{mmHg}$, the PVR threshold above which the hazard ratio for mortality increased was 2.2 WU. RATwATtE et al. [79] recently presented data on 82 patients (42 with CTD) with $\mathrm{mPAP} \geqslant 25 \mathrm{mmHg}$, PAWP $\leqslant 15 \mathrm{mmHg}$ but PVR $<3$ WU (median (interquartile range) 2.2 (1.9-2.7) WU) who were all treated with PAH-specific therapy. They found that this haemodynamic picture was associated with impaired function and reduced survival but was also associated with functional response to PAH-specific therapy [79].

\section{SSc with MPAP 21-24 $\mathrm{mmHg}$}

Although the term "borderline pulmonary hypertension" was never adopted by international guidelines, several studies involving patients with mPAP 21-24 mmHg which were performed prior to changes in diagnostic thresholds in the sixth WSPH used this phrase (table 4). The majority of patients had a PVR $<3$ WU. These studies suggested that SSc with mPAP 21-24 mmHg is not a benign condition, being associated with a risk of haemodynamic progression and functional impairment [80-83, 85]. 
TABLE 4 Key observational studies in systemic sclerosis (SSc) patients with mean pulmonary arterial pressure (mPAP) 21-24 mmHg

\begin{tabular}{|c|c|c|c|c|}
\hline $\begin{array}{l}\text { First author } \\
\text { [ref.] }\end{array}$ & Year & $\begin{array}{c}\text { Patients } \\
\mathrm{n}\end{array}$ & PVR & Key findings \\
\hline BAE $[80]^{\#}$ & 2012 & 28 & $2.6 \pm 1.4 \mathrm{WU}$ & $\begin{array}{l}206 \text { patients from the PHAROS registry ( } 35 \mathrm{mPAP} \leqslant 20 \mathrm{mmHg}, 28 \mathrm{mPAP} 21-24 \mathrm{mmHg}, 143 \\
\text { PH with mPAP } \geqslant 25 \mathrm{mmHg} \text { ) } \\
55 \% 21-24 \mathrm{mmHg} \text { group developed PH (mean follow-up } 26 \text { months) } \\
88 \% 21-24 \mathrm{mmHg} \text { group also had an increase in mPAP at exercise which fulfilled the } 3 \mathrm{rd} \\
\text { WSPH criteria for PH-exercise }\end{array}$ \\
\hline $\operatorname{VALERIO}[81]^{\#}$ & 2013 & 86 & $2.3 \pm 0.9 \mathrm{WU}$ & $\begin{array}{l}228 \mathrm{SSc} \text { patients ( } 86 \mathrm{mPAP} 21-24 \mathrm{mmHg}, 142 \mathrm{mPAP} \leqslant 20 \mathrm{mmHg} \text { ) } \\
19 \% 21-24 \mathrm{mmHg} \text { group developed PAH (mean follow-up } 45 \mathrm{months} \text { ) } \\
\text { In addition, } 1 \text { patient developed PH-LHD and } 1 \text { patient PH-lung } \\
\text { mPAP } 21-24 \mathrm{mmHg} \text { (HR 3.7) and TPG } \geqslant 11 \mathrm{mmHg} \text { (HR 7.9) predicted development of PAH } \\
\text { (both } \mathrm{p}<0.001 \text { ) }\end{array}$ \\
\hline VISOVATTI [82] & 2014 & 36 & $2.3 \pm 0.7 \mathrm{WU}$ & $\begin{array}{l}\text { Post-hoc analysis of } 244 \mathrm{SSc} \text { patients from the DETECT study cohort: } 60 \% \mathrm{mPAP} \\
\leqslant 20 \mathrm{mmHg}, 15 \% \mathrm{mPAP} 21-24 \mathrm{mmHg} \text { and } 25 \% \mathrm{PAH} \\
\text { Compared with mPAP } \leqslant 20 \mathrm{mmHg} \text {, mPAP } 21-24 \mathrm{mmHg} \text { associated with higher NT-proBNP, } \\
\text { more frequent peripheral oedema and larger left atria }\end{array}$ \\
\hline CoghLAN [83] $]^{\#}$ & 2018 & 21 & $2.4 \pm 0.8 \mathrm{WU}$ & $\begin{array}{l}71 \text { patients from the DETECT study cohort with baseline mPAP }<25 \mathrm{mmHg} \text { ( } 50 \mathrm{mPAP} \\
\leqslant 20 \mathrm{mmHg}, 21 \text { with } 21-24 \mathrm{mmHg} \text { ) had repeat RHC after a median of } 3 \text { years } \\
21-24 \mathrm{mmHg} \text { group had lower baseline } 6 \mathrm{MWD} \\
33.3 \% 21-24 \mathrm{mmHg} \text { group and } 22 \% \text { of } \mathrm{mPAP} \leqslant 20 \mathrm{mmHg} \text { developed } \mathrm{PAH} \text { ( } \mathrm{p}=0.026 \text { ) } \\
\text { Higher PVR, TRV, IVC diameter and lower } K_{\mathrm{CO}} \text { were predictive of subsequent PH } \\
\text { development }\end{array}$ \\
\hline $\begin{array}{l}\text { HOFFMANN-VOLD } \\
{[73]^{\#}}\end{array}$ & 2018 & 39 & Unknown & 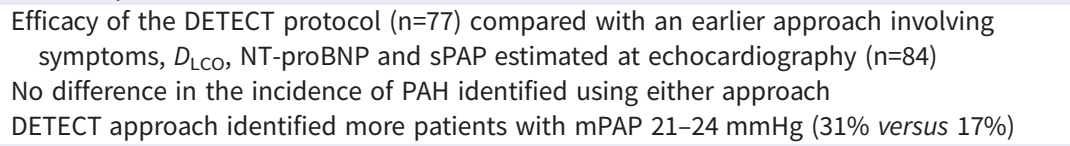 \\
\hline NAGEL [84] & 2019 & 14 & $2.3 \pm 0.4 \mathrm{WU}$ & $\begin{array}{l}\text { Compared with } 72 \text { patients with mPAP } \leqslant 20 \mathrm{mmHg}, 21-24 \mathrm{mmHg} \text { group had lower 6MWD } \\
(396 \pm 87 \mathrm{~m} \text { versus } 474 \pm 79 \mathrm{~m}, \mathrm{p}=0.008)\end{array}$ \\
\hline Xanthouli [76] & 2019 & 28 & $2.5 \pm 0.4 \mathrm{WU}$ & $\begin{array}{l}\text { Compared with } 123 \text { patients with mPAP } \leqslant 20 \mathrm{mmHg}, 21-24 \mathrm{mmHg} \text { group had lower 6MWD } \\
(414 \pm 100 \mathrm{~m} \text { versus } 488 \pm 101 \mathrm{~m}, \mathrm{p}<0.001) \text { and TAPSE }(21 \pm 6 \mathrm{~mm} \text { versus } 24 \pm 4 \mathrm{~mm}, \mathrm{p}=0.004)\end{array}$ \\
\hline
\end{tabular}

PVR: pulmonary vascular resistance; WU: Wood Units; PH: pulmonary hypertension; WSPH: World Symposium on Pulmonary Hypertension; LHD: left heart disease; TPG: transpulmonary gradient; PAH: pulmonary arterial hypertension; NT-proBNP: N-terminal pro-brain natriuretic peptide; RHC: right heart catheterisation; 6MWD: 6-min walk distance; TRV: tricuspid regurgitation velocity; IVC: inspiratory vital capacity; $K_{\mathrm{co}}$ : transfer coefficient of the lung for carbon monoxide; $D_{\text {LCo: }}$ diffusing capacity of the lung for carbon monoxide; SPAP: systolic pulmonary arterial pressure; TAPSE: tricuspid annular plane systolic excursion. ": published prior to the change in haemodynamic definition at the 6th WSPH.

\section{Summary}

Patients with mPAP $21-24 \mathrm{mmHg}$ are at risk of developing mPAP $\geqslant 25 \mathrm{mmHg}$ during follow-up. When compared with either the previous approach ( $\mathrm{mPAP} \geqslant 25 \mathrm{mmHg}$ and PVR $\geqslant 3 \mathrm{WU}$ ) or the sixth WSPH approach (mPAP $>20 \mathrm{mmHg}$ and PVR $\geqslant 3 \mathrm{WU}$ ), the use of an mPAP threshold of $>20 \mathrm{mmHg}$ and a PVR threshold of $\geqslant 2 \mathrm{WU}$ is likely to be a superior approach for identifying SSc patients with pulmonary vascular disease.

\section{SSc-PH-exercise}

An excessive increase in mPAP following increased pulmonary blood flow on exercise may result from several factors including increased PVR due to pulmonary vascular remodelling, obstruction or destruction, reduced pulmonary arterial distensibility or transmission of increased left atrial pressure due to LHD [26, 86-88]. The first WSPH report stated that "some forms of pulmonary hypertension are latent and become apparent only when there is an increase in blood flow" [14]. It commented that mPAP rarely exceeds $30 \mathrm{mmHg}$ on exercise, although it also subsequently stated that mPAP can increase to $>30 \mathrm{mmHg}$ during exercise in athletes or in the elderly [14]. As noted above, the diagnosis of exercise PH was introduced at the third WSPH in 2003 but, following a systematic review including data from 1187 healthy volunteers, it became apparent that the normal pressure response to exercise varies with age and exercise level and so defining an abnormal response by pressure alone was not possible [6]. The diagnosis of exercise $\mathrm{PH}$ was therefore removed at the fourth WSPH [17]. More recently, Herve et al. [89] studied 169 patients with resting $\mathrm{mPAP} \leqslant 20 \mathrm{mmHg}$ who underwent exercise-RHC. The addition of a total pulmonary resistance (TPR=mPAP/cardiac output) at maximal exercise of $>3 \mathrm{WU}$ to the previous criteria of $\mathrm{mPAP}>30 \mathrm{mmHg}$ increased the specificity in identifying patients with pulmonary vascular disease or LHD from 0.77 to 1.0 [89]. 
The ERS statement on pulmonary haemodynamics on exercise consequently suggested that "exercise pulmonary hypertension may be defined as the presence of resting mPAP $<25 \mathrm{mmHg}$ and mPAP $>30 \mathrm{mmHg}$ during exercise with total pulmonary resistance $>3$ WU” [86]. The sixth WSPH, however, did not recommend the return of a formal exercise $\mathrm{PH}$ diagnosis, citing the difficulty in distinguishing exercise-related changes due to pulmonary vascular disease from those due to exercise-related increases in PAWP, especially given the practical difficulties in measuring PAWP on exercise and the uncertainty regarding normal values [5].

A number of studies have investigated the prevalence of SSc-PH-exercise with estimates ranging between $7 \%$ and $48 \%$. In the majority of studies, however, exercise echocardiography rather than RHC was employed and so the true prevalence is not known. Conduffe et al. [90] identified 42 patients in the UK who met the third WSPH definition of SSc-PH-exercise and observed that $18 \%$ of patients developed resting SSc-PAH during a mean follow-up of 2.3 years. SтAмм et al. [91] studied 28 SSc-PH-exercise patients and noted that mean survival (5.2 years) was similar to that of 17 patients with SSc-PH at rest (4.4 years). ZEDER et al. [92] recently studied $80 \mathrm{SSc}$ patients with a resting mPAP $<25 \mathrm{mmHg}$ and observed that TPR and PVR at exercise, but not at rest, predicted subsequent survival.

\section{Summary}

Exercise haemodynamics provide an opportunity to identify latent pulmonary vascular disease. At exercise, a mPAP $>30 \mathrm{mmHg}$ plus a TPR $>3$ WU identifies patients with pulmonary vascular or left heart disease. Technical difficulties in measuring PAWP and uncertainty regarding its normal value on exercise mean that distinguishing between these states is currently difficult.

\section{Therapy in patients with mPAP 21-24 $\mathrm{mmHg}$ and SSc-PH-exercise}

There are limited data on the effects of PAH-specific therapies in patients with mPAP 21-24 mmHg or SSc-PH-exercise. Kovacs et al. [93] studied 10 patients with mPAP 21-24 mmHg (PVR 2 \pm 0.8 WU) who underwent RHC at baseline, 1-year follow-up and after 6 months of treatment with bosentan. Pulmonary artery pressures worsened during the first year of observation but were then noted to stabilise during the 6 months of therapy while PVR worsened during the observation period but then significantly improved following therapy [93]. SAGGAR et al. [94] studied 12 patients with SSc-PH-exercise and noted significant improvements in both resting and exercise haemodyamics and 6MWD after 6 months of ambrisentan. PAN et al. [95] randomised 38 patients with mPAP 21-24 mmHg or SSc-PH-exercise to 6 months of ambrisentan or placebo. Although there was no significant effect on mPAP, ambrisentan was associated with significant improvements in PVR and cardiac index and a trend towards improved 6MWD.

\section{Summary}

Adequately powered RCTs of PAH therapies involving SSc patients with mPAP 21-24 mmHg and PH-exercise are required.

\section{SSC-PVOD}

Pulmonary veno-occlusive disease is a rare form of PH with significant involvement of pulmonary venules and veins [96]. The incidence of idiopathic disease is 0.5 per million per year [96, 97]. It can be autosomal recessively transmitted due to mutations in the EIF2AK4 gene [98]. It can also develop following exposure to alkylating chemotherapy agents or organic solvents [99, 100]. An association with SSc has also been recognised [11, 40, 101]. It is characterised histologically by occlusive venous intimal fibrous thickening [102]. Alveolar capillaries are often dilated due to downstream obstruction and angioproliferative lesions identical to those seen in pulmonary capillary haemangiomatosis are present in the majority of cases [103]. Pulmonary arterial involvement with intimal fibrosis and medial hypertrophy may also be present, although plexiform lesions are not seen. In the second WSPH, PVOD was classified as pulmonary venous hypertension (group 2.4). Since pulmonary haemodynamics are indistinguishable from those seen in $\mathrm{PAH}$, PVOD was moved into group 1 disease (1.4.1) in the third WSPH [16]. A separate grouping of 1' was devised for the fourth WSPH [17]. In recognition of the fact that PVOD can involve the pulmonary arterial, capillary and venous bed, the sixth WSPH defined a new classification (1.6): PAH with overt features of venous/capillaries (PVOD/PCH) involvement [5]. PVOD is characterised at lung function testing by significantly reduced $D_{\mathrm{LCO}}$ and radiologically by septal lines, centrilobular ground-glass changes and mediastinal lymphadenopathy [10].

GÜNTHER et al. [10] reviewed high-resolution computed tomography (HRCT) images for 26 SSc patients with pre-capillary $\mathrm{PH}$ and reported septal lines in $89 \%$, centrilobular ground-glass opacities in $46 \%$ and mediastinal lymphadenopathy in 58\%. The presence of $\geqslant 2$ radiographic signs was associated with subsequent pulmonary oedema following commencement of PAH-specific therapy. DoRfmÜLLER et al. [11] 
compared tissue samples from eight patients with CTD-PAH to samples from 29 IPAH patients. Pulmonary vein and venule obstructive lesions were present in $75 \%$ of CTD-PAH patients but only $17 \%$ of the IPAH group [11]. In addition, 50\% of the CTD patients had developed pulmonary oedema following commencement of PAH-specific therapy. GuPTA et al. [104] recently reported features of PVOD in 15 out of 18 patients with SSc-PH-ILD who had undergone lung transplantation. It must be noted that the incidence of pulmonary oedema in these studies was significantly higher than is seen in routine clinical practice and that extrapolating the high incidences of PVOD observed in highly selected histopathological studies to the general SSc population is difficult. Nevertheless, PVOD should be considered if clinical deterioration occurs following commencement of PAH-specific therapy in patients with SSc. Survival in PVOD is poor and early transplant referral in suitable patients is recommended [105-107].

\section{Summary}

SSc is not only associated with the development of overt PVOD but it is likely that a proportion of patients with SSc-PAH have a PVOD component to their disease.

\section{SSC-PH-LHD}

Primary cardiac involvement in SSc may involve the myocardium, pericardium, conduction system and valves, with estimates of overall prevalence of clinically overt disease of 7-39\% [108, 109]. Myocardial involvement may result from fibrosis or microvascular disease [110, 111] while LHD may also develop due to comorbidities such as systemic hypertension and coronary arterial disease. De LucA et al. [112] demonstrated greater levels of fibrosis at endomyocardial biopsy and a greater tendency of heart failure in 12 patients with SSc-associated myocarditis compared with 12 patients with idiopathic myocarditis and 10 patients with myocarditis associated with other forms of autoimmune disease. Cardiac magnetic resonance imaging (MRI) may demonstrate myocardial abnormalities even in the absence of overt cardiac dysfunction. For example, PoINDron et al. [113] identified evidence of diffuse myocardial fibrosis using T1 mapping at cardiac MRI in 36 out of 72 unselected SSc patients, despite there being no difference in right or left ventricular volumes or ejection fraction between those with or without elevated T1. NTUSI et al. [114] demonstrated increased focal myocardial fibrosis (late gadolinium enhancement) and mycocardial oedema (using T2 mapping) in addition to higher T1 levels in 19 SSc patients compared with 20 controls. Although biventricular size and global ventricular function were preserved, impairment of peak systolic circumferential strain and peak diastolic strain rate, which correlated inversely with the level of diffuse myocardial fibrosis, were observed in the SSc group. Using echocardiography, TennøE et al. [115] observed left ventricular diastolic dysfunction in 17\% of 275 SSc patients at baseline and in 29\% of patients after a median of 3.4 years follow-up. Allanore et al. [116] identified reduced left ventricular systolic function at echocardiography in $5.4 \%$ of 7073 patients in the European Scleroderma Trials and Research Group database. Patients without evidence of left ventricular dysfunction using standard echocardiography may have evidence of early "sub-clinical” disease using newer techniques. GUERRA et al. [117] compared global longitudinal strain by performing speckle tracking echocardiography in 52 SSc patients without PH or known LHD and 52 age-matched controls. They observed a 2.5-fold increased risk of subclinical left ventricular systolic impairment and a 3.3-fold increased risk of subclinical right ventricular systolic impairment. D’Alto et al. [118] recently compared the response to fluid challenge in 25 SSc patients without $\mathrm{PH}$ and 25 healthy controls and concluded that SSc patients have an increased frequency of subclinical LV diastolic dysfunction.

Patients diagnosed with SSc-PAH may have co-existing LHD or occult PH-LHD. FISHER et al. [35] demonstrated LV diastolic dysfunction in 33\% of patients who fulfilled haemodynamic diagnostic criteria for SSc-PAH but in only 10\% of patients diagnosed with IPAH. Fox et al. [119] reclassified 11 (48\%) out of 29 SSc-PAH patients with PH-LHD following a fluid challenge; mean left atrial dimension was higher in the reclassified patients. RoBBins et al. [120] subsequently performed a fluid challenge in 207 patients (49\% with an underlying CTD) who met haemodynamic diagnostic criteria for PAH. 46 patients (22\%) were reclassified with PH-LHD; body mass index was higher and there was a higher frequency of systemic hypertension, diabetes and left atrial enlargement when compared with those patients who were not reclassified [120].

Differentiating between SSc-PAH and SSc-PH-LHD purely on the basis of haemodynamics may be problematic given the difficulties that can be experienced in obtaining reliable PAWP measurements. LAMmI et al. [121] observed that 30\% of 120 patients in the PHAROS registry with repeat RHC changed their PH classification group at follow-up. Patients' pre-test probability for SSc-PAH or SSc-PH-LHD should therefore be assessed by considering risk factors (such as systemic hypertension, obesity and diabetes), ECG, left atrial size and markers of diastolic dysfunction on echocardiography [103]. It is 
recommended that PAWP is measured at end-expiration and that blood oxygen saturation in the wedged position should be checked to ensure that a reliable wedged position has been achieved [122].

PH-LHD may exist as a purely passive process whereby increased left ventricular filling pressures are transmitted backwards through the pulmonary circulation [21]. The fifth WSPH introduced the term isolated post-capillary $\mathrm{PH}$ (table 1) to describe the clinical state which is currently defined as mPAP $>20 \mathrm{mmHg}$, PAWP >15 mmHg and PVR <3 WU (table 2) [21]. In some patients with PH-LHD, however, processes such as increased endothelin-1, inflammatory cellular infiltrate and reduced nitric oxide-induced vasodilation, can result in the development of an additional pulmonary vasculopathy [21]. These patients develop an increased PVR and are more likely to have features of PAH such as severely elevated mPAP and significant RV dilatation and dysfunction [123]. This state is termed combined pre- and post-capillary $\mathrm{PH}(\mathrm{CpcPH})$ and is defined as $\mathrm{mPAP}>20 \mathrm{mmHg}$, PAWP $>15 \mathrm{mmHg}$ and PVR $\geqslant 3 \mathrm{WU}$ [21]. Patients with $\mathrm{CpcPH}$ typically also have an elevated transpulmonary gradient (TPG=mPAP-PAWP) $>12 \mathrm{mmHg}$ and a diastolic pulmonary artery pressure to PAWP gradient $\geqslant 7 \mathrm{mmHg}$.

$20 \%$ of patients with SSc-PH in a large multicentre cohort were diagnosed with SSc-PH-LHD [27]. The commonest form of SSc-PH-LHD is that associated with heart failure with preserved ejection fraction (SSc-PH-HFpEF). BourJi et al. [124] compared 93 SSc-PAH patients with 24 SSc-PH-HFpEF patients. Patients with SSc-PH-HFpEF had higher body mass index, mPAP and PAWP and larger left atria but similar TPG to patients with SSc-PAH. Survival in SSc-HFpEF, when adjusted for haemodynamics, was inferior [124].

A number of RCTs have assessed the role of PAH-specific therapies in patients with PH-LHD [125-128]. Apart from a small study by GuAzzi et al. [126] involving 44 patients treated with sildenafil which reported improvements in PVR and cardiopulmonary exercise test parameters, the published studies, to date, have failed to reach their primary end-points. Only one of these studies, the MELODY-1 trial, enrolled patients with $\mathrm{CpcPH}$. There are a lack of data assessing response to PAH-specific therapies in SSc-PH-LHD.

\section{Summary}

The incidence of subclinical and overt LHD is increased in patients with SSc. A fluid challenge should be considered in patients with an increased pre-test probability of PH-LHD who have a PAWP of 13$15 \mathrm{mmHg}$. Treatment of underlying LHD should be optimised. Further data are needed regarding response to PAH therapies, especially in patients with SSc-CpcPH.

\section{SSC-PH-ILD}

Interstitial changes are visible on HRCT in up to $80 \%$ of SSc patients while clinically overt ILD is present in up to $40 \%$ [129]. The majority of SSc patients with ILD have nonspecific interstitial pneumonia with usual interstitial pneumonia being present in $<10 \%$ of cases [130-132]. SSc-ILD is more common in DcSSc, in older patients at disease onset and in black and male patients [133-135]. Typically, ILD occurs within the first 3 years from diagnosis in DcSSc [135] while it develops later in LcSSc [136]. GoH et al. [137] observed poorer outcomes in SSc patients with extensive disease (defined as $>20 \%$ lung involvement on HRCT or forced vital capacity (FVC) $<70 \%$ in indeterminate cases) as opposed to limited disease. There are, however, no data validating the optimal threshold of lung involvement to differentiate SSc-PH-ILD from SSc-PAH. Some studies of SSc-PH-ILD have adopted the system of GoH et al. [137] while other studies have used a range of criteria including: the presence of any ILD [129, 138]; fibrosis extent $>5 \%$ plus total lung capacity (TLC) or FVC $<70 \%$ [139]; TLC $<70 \%$ or moderate-severe fibrosis plus TLC $60-70 \%$ [140]; fibrosis extent $>33 \%$ or FVC $<60 \%$ [90]. LAUNAY et al. [141] also used the system of GoH et al. [137] during their cluster analysis of 200 SSc patients with pre-capillary PH. In this study the presence of extensive ILD (cluster 2) was associated with significantly poorer survival while the presence or absence of limited ILD in the other three clusters did not appear to have prognostic importance. ANTONIou et al. [142] identified combined fibrosis and emphysema in $12 \%$ of SSc patients with ILD including in $7.5 \%$ of life-long nonsmokers. Combined fibrosis and emphysema is associated with an increased risk of PH. CotTIN et al. [143] demonstrated PH in five out of 10 SSc patients with combined fibrosis and emphysema.

Several studies have reported poorer survival in patients with SSc-PH-ILD compared with SSc-PAH [90, 138-140]. Meta-analysis in 2013 demonstrated 3-year survival of 56\% in SSc-PAH and 35\% in SSc-PH-ILD [9]. In a study of 39 SSc-PAH and 20 SSc-PH-ILD patients, MATHAi et al. [140] found independent prognostic factors to be a diagnosis of SSc-PH-ILD, the presence of DcSSc, PVR index and $D_{\text {Lco. }}$ Similarly, Chauvelot et al. [138] observed that the presence of ILD, together with chronic kidney 
disease and a lower 6MWD, was an independent prognostic factor in a study involving 68 SSc-PH-ILD and 62 SSc-PAH patients. Response to PAH-specific therapies appears to be reduced in patients with SSc-PH-ILD. Le PAVEC et al. [144] studied 70 patients with SSc-PH-ILD and demonstrated no improvements in WHO FC, 6MWD or pulmonary haemodynamics following institution of PAH therapies. CHAUvelot et al. [138] observed poorer survival and lower frequency of improvement in WHO FC in SSc-PH-ILD compared with SSc-PAH patients.

Previous RCTs of PAH therapies in patients with non-CTD associated ILD \pm PH have either been negative [145] or associated with adverse outcomes [146, 147]. However, WAXMAN et al. [148] recently published the results of the INCREASE study which included $72 \mathrm{PH}$ patients with CTD-associated ILD (CTD-PH-ILD) who were randomised to nebulised treprostinil or placebo for 16 weeks. Receiving treprostinil was associated with significant benefits in NT-proBNP and clinical deterioration (both $\mathrm{p}<0.05$ ) while there was an improvement in 6MWD of $44 \mathrm{~m}$ in the CTD-ILD-PH patients (95\% CI 10.77). There was, however, no effect of therapy on quality of life.

\section{Summary}

Survival in SSc-PH-ILD is worse than in SSc-PAH. Most observational studies have reported a lack of functional and haemodynamic response to PAH therapies in patients with SSc-PH-ILD. Further RCTs of PAH therapies specifically in SSc-PH-ILD are needed.

Conclusion

Several different and overlapping forms of $\mathrm{PH}$ can present in patients with SSc. Accurate and early diagnosis to allow optimal treatment is therefore essential. Therapeutic uncertainty exists for SSc-PAH patients with mild pulmonary haemodynamics, SSc-PH-LHD or SSc-PH-ILD and further studies in these groups are urgently needed. Furthermore, the optimal PVR threshold for diagnosing PAH and the role of exercise in identifying early disease requires further elucidation.

Provenance: Submitted article, peer reviewed.

Conflict of interest: A. Haque has nothing to disclose. D.G. Kiely reports personal fees and non-financial support from Bayer, GSK, Janssen and MSD, outside the submitted work. G. Kovacs reports personal fees and non-financial support from Bayer, GSK, Janssen, MSD, Boehringer Ingelheim, Novartis, Chiesi and Vitalaire, outside the submitted work. A.A.R. Thompson reports personal fees and non-financial support from Janssen, outside the submitted work. R. Condliffe reports personal fees and non-financial support from Bayer, GSK, Janssen and MSD, outside the submitted work.

Support statement: This review was funded by the British Heart Foundation (Intermediate Clinical Fellowship FS/ 18/13/3328). Funding information for this article has been deposited with the Crossref Funder Registry.

\section{References}

1 Denton CP, Khanna D. Systemic sclerosis. Lancet 2017; 390: 1685-1699.

2 Stochmal A, Czuwara J, Trojanowska M, et al. Antinuclear antibodies in systemic sclerosis: an update. Clin Rev Allergy Immunol 2020; 58: 40-51.

3 Distler $\mathrm{O}$, Allanore $\mathrm{Y}$, Denton $\mathrm{CP}$, et al. Factors influencing early referral, early diagnosis and management in patients with diffuse cutaneous systemic sclerosis. Rheumatol 2018; 57: 813-817.

4 Kiely DG, Elliot CA, Sabroe I, et al. Pulmonary hypertension: diagnosis and management. BMJ 2013; 346: f2028.

5 Simonneau G, Montani D, Celermajer DS, et al. Haemodynamic definitions and updated clinical classification of pulmonary hypertension. Eur Respir J 2019; 53: 1801913.

6 Galiè N, Humbert M, Vachiery J-L, et al. 2015 ESC/ERS Guidelines for the diagnosis and treatment of pulmonary hypertension. Eur Heart J 2016; 37: 67-119.

7 Campo A, Mathai SC, Le Pavec J, et al. Hemodynamic predictors of survival in scleroderma-related pulmonary arterial hypertension. Am J Respir Crit Care Med 2010; 182: 252-260.

8 Van Der Bruggen CEE, Tedford RJ, Handoko ML, et al. RV pressure overload: from hypertrophy to failure. Cardiovasc Res 2017; 113: 1423-1432.

9 Lefèvre G, Dauchet L, Hachulla E, et al. Survival and prognostic factors in systemic sclerosis-associated pulmonary hypertension: a systematic review and meta-analysis. Arthritis Rheum 2013; 65: 2412-2423.

10 Günther S, Jaïs X, Maitre S, et al. Computed tomography findings of pulmonary venoocclusive disease in scleroderma patients presenting with precapillary pulmonary hypertension. Arthritis Rheum 2012; 64: 2995-3005. 
Dorfmüller P, Humbert M, Perros F, et al. Fibrous remodeling of the pulmonary venous system in pulmonary arterial hypertension associated with connective tissue diseases. Hum Pathol 2007; 38: 893-902.

Overbeek MJ, Vonk MC, Boonstra A, et al. Pulmonary arterial hypertension in limited cutaneous systemic sclerosis: a distinctive vasculopathy. Eur Respir J 2008; 34: 371-379.

Schoenfeld SR, Choi HK, Sayre EC, et al. Risk of pulmonary embolism and deep venous thrombosis in systemic sclerosis: a general population-based study. Arthritis Care Res 2016; 68: 246-253.

Hatano S, Strasser T, World Health Organization. Primary Pulmonary Hypertension: Report on a WHO meeting. Geneva, World Health Organization, 1975.

Rich S. Primary Pulmonary Hypertension: Executive Summary from the World Symposium - Primary Pulmonary Hypertension 1998. http://www.wsphassociation.org/wp-content/uploads/2019/04/PrimaryPulmonary-Hypertension-Evian-1998.pdf

Barst RJ, McGoon M, Torbicki A, et al. Diagnosis and differential assessment of pulmonary arterial hypertension. J Am Coll Cardiol 2004; 43: S40-S47.

Badesch DB, Champion HC, Gomez Sanchez MA, et al. Diagnosis and assessment of pulmonary arterial hypertension. J Am Coll Cardiol 2009; 54: S55-S66.

Hoeper MM, Barberà JA, Channick RN, et al. Diagnosis, assessment, and treatment of non-pulmonary arterial hypertension pulmonary hypertension. J Am Coll Cardiol 2009; 54: S85-S96.

Hoeper MM, Bogaard HJ, Condliffe R, et al. Definitions and diagnosis of pulmonary hypertension. J Am Coll Cardiol 2013; 62: D42-D50.

Vachiéry JL, Tedford RJ, Rosenkranz S, et al. Pulmonary hypertension due to left heart disease. Eur Respir J 2019; 53: 1801897.

Vachiéry J-L, Adir Y, Barberà JA, et al. Pulmonary hypertension due to left heart diseases. J Am Coll Cardiol 2013; 62: D100-D108.

Chronic cor pulmonale. Report of an expert committee. World Health Organ Tech Rep Ser 1961; 213: 35.

Kovacs G, Berghold A, Scheidl S, et al. Pulmonary arterial pressure during rest and exercise in healthy subjects: a systematic review. Eur Respir J 2009; 34: 888-894.

Maron BA, Hess E, Maddox TM, et al. Association of borderline pulmonary hypertension with mortality and hospitalization in a large patient cohort: insights from the Veterans Affairs clinical assessment, reporting, and tracking program. Circulation 2016; 133: 1240-1248.

Kolte D, Lakshmanan S, Jankowich MD, et al. Mild pulmonary hypertension is associated with increased mortality: a systematic review and meta-analysis. J Am Heart Assoc 2018; 7: e009729.

Condliffe R. Unmasking hidden disease: exercise pulmonary haemodynamics in systemic sclerosis. Eur Respir J 2017; 50: 1700885.

Avouac J, Airò P, Meune C, et al. Prevalence of pulmonary hypertension in systemic sclerosis in European Caucasians and metaanalysis of 5 studies. J Rheumatol 2010; 37: 2290-2298.

Rubio-Rivas M, Homs NA, Cuartero D, et al. The prevalence and incidence rate of pulmonary arterial hypertension in systemic sclerosis: systematic review and meta-analysis. Autoimmun Rev 2021; 20: 102713.

Hachulla E, De Groote P, Gressin V, et al. The three-year incidence of pulmonary arterial hypertension associated with systemic sclerosis in a multicenter nationwide longitudinal study in France. Arthritis Rheum 2009; 60: 1831-1839.

Koh ET, Lee P, Gladman DD, et al. Pulmonary hypertension in systemic sclerosis: an analysis of 17 patients. Br J Rheumatol 1996; 35: 989-993.

Kawut SM, Taichman DB, Archer-Chicko CL, et al. Hemodynamics and survival in patients with pulmonary arterial hypertension related to systemic sclerosis. Chest 2003; 123: 344-350.

Chung L, Liu J, Parsons L, et al. Characterization of connective tissue disease-associated pulmonary arterial hypertension from REVEAL: identifying systemic sclerosis as a unique phenotype. Chest 2010; 138: 1383-1394.

Clements PJ, Tan M, McLaughlin VV, et al. The pulmonary arterial hypertension quality enhancement research initiative: comparison of patients with idiopathic $\mathrm{PAH}$ to patients with systemic sclerosis-associated PAH. Ann Rheum Dis 2012; 71: 249-252.

Hurdman J, Condliffe R, Elliot CA, et al. ASPIRE registry: Assessing the Spectrum of Pulmonary hypertension Identified at a REferral centre. Eur Respir J 2012; 39: 945-955.

Fisher MR, Mathai SC, Champion HC, et al. Clinical differences between idiopathic and scleroderma-related pulmonary hypertension. Arthritis Rheum 2006; 54: 3043-3050.

Ramjug S, Hussain N, Hurdman J, et al. Long-term outcomes of domiciliary intravenous iloprost in idiopathic and connective tissue disease-associated pulmonary arterial hypertension. Respirology 2017; 22: 372-377.

3 Ramjug S, Hussain N, Hurdman J, et al. Idiopathic and systemic sclerosis-associated pulmonary arterial hypertension: a comparison of demographic, hemodynamic, and MRI characteristics and outcomes. Chest 2017; 152: 92-102. 
Coghlan JG, Schreiber B. An update on the evaluation and management of pulmonary hypertension in scleroderma. Curr Rheumatol Rep 2012; 14: 1-10.

Condliffe R, Howard LS. Connective tissue disease-associated pulmonary arterial hypertension. F1000Prime Rep 2015; 7: 6.

Dorfmüller P, Montani D, Humbert M. Beyond arterial remodelling: pulmonary venous and cardiac involvement in patients with systemic sclerosis associated pulmonary arterial hypertension. Eur Respir $J$ 2010; 35: 6-8.

Overbeek MJ, Mouchaers KTB, Niessen HM, et al. Characteristics of interstitial fibrosis and inflammatory cell infiltration in right ventricles of systemic sclerosis-associated pulmonary arterial hypertension. Int $J$ Rheumatol 2010; 2010: 604615.

Tedford RJ, Mudd JO, Girgis RE, et al. Right ventricular dysfunction in systemic sclerosis-associated pulmonary arterial hypertension. Circ Heart Fail 2013; 6: 953-963.

Mathai SC, Bueso M, Hummers LK, et al. Disproportionate elevation of $\mathrm{N}$-terminal pro-brain natriuretic peptide in scleroderma-related pulmonary hypertension. Eur Respir J 2010; 35: 95-104.

Hsu S, Kokkonen-Simon KM, Kirk JA, et al. Right ventricular myofilament functional differences in humans with systemic sclerosis-associated versus idiopathic pulmonary arterial hypertension. Circulation 2018; 137: 2360-2370.

Humbert M, Lau EMT, Montani D, et al. Advances in therapeutic interventions for patients with pulmonary arterial hypertension. Circulation 2014; 130: 2189-2208.

Sommer N, Ghofrani HA, Pak O, et al. Current and future treatments of pulmonary arterial hypertension. Br J Pharmacol 2021; 178: 6-30.

Galiè N, Ghofrani HA, Torbicki A, et al. Sildenafil citrate therapy for pulmonary arterial hypertension. N Engl J Med 2005; 353: 2148-2157.

Badesch DB, Hill N, Burgess G, et al. Sildenafil for pulmonary arterial hypertension associated with connective tissue disease. J Rheumatol 2007; 34: 2417-2422.

Galiè N, Brundage BH, Ghofrani HA, et al. Tadalafil therapy for pulmonary arterial hypertension. Circulation 2009; 119: 2894-2903.

Galiè N, Denton CP, Dardi F, et al. Tadalafil in idiopathic or heritable pulmonary arterial hypertension (PAH) compared to PAH associated with connective tissue disease. Int J Cardiol 2017; 235: 67-72.

Ghofrani HA, Galiè N, Grimminger F, et al. Riociguat for the treatment of pulmonary arterial hypertension. N Engl J Med 2013; 369: 330-340.

Humbert M, Coghlan JG, Ghofrani HA, et al. Riociguat for the treatment of pulmonary arterial hypertension associated with connective tissue disease: results from PATENT-1 and PATENT-2. Ann Rheum Dis 2017; 76: 422-426.

Rubin LJ, Badesch DB, Barst RJ, et al. Bosentan therapy for pulmonary arterial hypertension. N Engl J Med 2002; 346: 896-903.

Coghlan JG, Galiè N, Barberà JA, et al. Initial combination therapy with ambrisentan and tadalafil in connective tissue disease-associated pulmonary arterial hypertension (CTD-PAH): subgroup analysis from the AMBITION trial. Ann Rheum Dis 2017; 76: 1219-1227.

Galiè N, Barberà JA, Frost $A E$, et al. Initial use of ambrisentan plus tadalafil in pulmonary arterial hypertension. N Engl J Med 2015; 373: 834-844.

Pulido T, Adzerikho I, Channick RN, et al. Macitentan and morbidity and mortality in pulmonary arterial hypertension. N Engl J Med 2013; 369: 809-818.

Barst RJ, Rubin LJ, Long WA. A comparison of continuous intravenous epoprostenol (prostacyclin) with conventional therapy for primary pulmonary hypertension. N Engl J Med 1996; 334: 296-301.

Badesch DB, Tapson VF, McGoon MD, et al. Continuous intravenous epoprostenol for pulmonary hypertension due to the scleroderma spectrum of disease: a randomized, controlled trial. Ann Intern Med 2000; 132: 425-434.

Simonneau G, Barst RJ, Galie N, et al. Continuous subcutaneous infusion of treprostinil, a prostacyclin analogue, in patients with pulmonary arterial hypertension: a double-blind, randomized, placebo-controlled trial. Am J Respir Crit Care Med 2002; 165: 800-804.

Oudiz RJ, Schilz RJ, Barst RJ, et al. Treprostinil, a prostacyclin analogue, in pulmonary arterial hypertension associated with connective tissue disease. Chest 2004; 126: 420-427.

Gaine S, Chin K, Coghlan G, et al. Selexipag for the treatment of connective tissue disease-associated pulmonary arterial hypertension. Eur Respir J 2017; 50: 1602493.

Sitbon O, Channick R, Chin KM, et al. Selexipag for the treatment of pulmonary arterial hypertension. N Eng J Med 2015; 373: 2522-2533.

Khanna D, Zhao C, Saggar R, et al. Long-term outcomes in patients with connective tissue disease-associated pulmonary arterial hypertension in the modern treatment era: meta-analyses of randomized, controlled trials and observational registries. Br J Pharmacol 2021; 73: 837-847. 
Rhee RL, Gabler NB, Sangani S, et al. Comparison of treatment response in idiopathic and connective tissue disease-associated pulmonary arterial hypertension. Am J Respir Crit Care Med 2015; 192: 1111-1117.

Badesch DB, McGoon MD, Barst RJ, et al. Longterm survival among patients with scleroderma-associated pulmonary arterial hypertension treated with intravenous epoprostenol. J Rheumatol 2009; 36: 2244-2249.

Humbert M, Yaici A, De Groote P, et al. Screening for pulmonary arterial hypertension in patients with systemic sclerosis: clinical characteristics at diagnosis and long-term survival. Arthritis Rheum 2011; 63: 3522-3530.

White RJ, Vonk-Noordegraaf A, Rosenkranz S, et al. Clinical outcomes stratified by baseline functional class after initial combination therapy for pulmonary arterial hypertension. Respir Res 2019; 20: 208.

Condliffe R, Kovacs G. Identifying early pulmonary arterial hypertension in patients with systemic sclerosis. Eur Respir J 2018; 51: 1800495.

Coghlan JG, Denton CP, Grünig E, et al. Evidence-based detection of pulmonary arterial hypertension in systemic sclerosis: the DETECT study. Ann Rheum Dis 2014; 73: 1340-1349.

Thakkar V, Stevens W, Prior D, et al. The inclusion of N-terminal pro-brain natriuretic peptide in a sensitive screening strategy for systemic sclerosis-related pulmonary arterial hypertension: a cohort study. Arthritis Res Ther 2013; 15: R193.

Hao Y, Thakkar V, Stevens W, et al. A comparison of the predictive accuracy of three screening models for pulmonary arterial hypertension in systemic sclerosis. Arthritis Res Ther 2015; 17: 7.

Weatherald J, Montani D, Jevnikar M, et al. Screening for pulmonary arterial hypertension in systemic sclerosis. Eur Respir Rev 2019; 28: 190023.

Hoffmann-Vold AM, Fretheim H, Midtvedt $\varnothing$, et al. Frequencies of borderline pulmonary hypertension before and after the DETECT algorithm: results from a prospective systemic sclerosis cohort. Rheumatol (Oxford) 2018; 57: 480-487.

Jaafar S, Visovatti S, Young A, et al. Impact of the revised haemodynamic definition on the diagnosis of pulmonary hypertension in patients with systemic sclerosis. Eur Respir J 2019; 54: 1900586.

Kovacs G, Olschewski H. Debating the new haemodynamic definition of pulmonary hypertension: much ado about nothing? Eur Respir J 2019; 54: 1901278.

Xanthouli $\mathrm{P}$, Jordan S, Milde N, et al. Haemodynamic phenotypes and survival in patients with systemic sclerosis: the impact of the new definition of pulmonary arterial hypertension. Ann Rheum Dis 2019; 79: 370-378.

Kovacs G, Olschewski A, Berghold A, et al. Pulmonary vascular resistances during exercise in normal subjects: A systematic review. Eur Respir J 2012; 39: 319-328.

Maron BA, Brittan EL, Hess E, et al. Pulmonary vascular resistance and clinical outcomes in patients with pulmonary hypertension: a retrospective cohort study. Lancet Respir Med 2020; 8: 873-884.

Ratwatte S, Anderson J, Strange G, et al. Pulmonary arterial hypertension with below threshold pulmonary vascular resistance. Eur Respir J 2020; 56: 1901654.

Bae S, Saggar R, Bolster MB, et al. Baseline characteristics and follow-up in patients with normal haemodynamics versus borderline mean pulmonary arterial pressure in systemic sclerosis: results from the PHAROS registry. Ann Rheum Dis 2012; 71: 1335-1342.

Valerio CJ, Schreiber BE, Handler CE, et al. Borderline mean pulmonary artery pressure in patients with systemic sclerosis: transpulmonary gradient predicts risk of developing pulmonary hypertension. Arthritis Rheum 2013; 65: 1074-1084.

Visovatti SH, Distler O, Coghlan JG, et al. Borderline pulmonary arterial pressure in systemic sclerosis patients: a post-hoc analysis of the DETECT study. Arthritis Res Ther 2014; 16: 493.

Coghlan GJ, Wolf M, Distler O, et al. Incidence of pulmonary hypertension and determining factors in patients with systemic sclerosis. Eur Respir J 2018; 51: 1701197.

Nagel C, Marra AM, Benjamin N, et al. Reduced right ventricular output reserve in patients with systemic sclerosis and mildly elevated pulmonary artery pressure. Arthritis Rheumatol 2019; 71: 805-816.

Kovacs G, Douschan P, Maron BA, et al. Mildly increased pulmonary arterial pressure: a new disease entity or just a marker of poor prognosis? Eur J Heart Fail 2019; 21: 1057-1061.

Kovacs G, Herve P, Barbera JA, et al. An official European Respiratory Society statement: pulmonary haemodynamics during exercise. Eur Respir J 2017; 50: 1601708.

Lau EMT, Chemla D, Godinas L, et al. Loss of vascular distensibility during exercise is an early hemodynamic marker of pulmonary vascular disease. Chest 2016; 149: 353-361.

Maor E, Grossman Y, Balmor RG, et al. Exercise haemodynamics may unmask the diagnosis of diastolic dysfunction among patients with pulmonary hypertension. Eur J Heart Fail 2015; 17: 151-158.

Herve P, Lau EM, Sitbon 0 , et al. Criteria for diagnosis of exercise pulmonary hypertension. Eur Respir $J$ 2015; 46: 728-737.

Condliffe R, Kiely DG, Peacock AJ, et al. Connective tissue disease-associated pulmonary arterial hypertension in the modern treatment era. Am J Respir Crit Care Med 2009; 179: 151-157. 
91 Stamm A, Saxer S, Lichtblau M, et al. Exercise pulmonary haemodynamics predict outcome in patients with systemic sclerosis. Eur Respir J 2016; 48: 1658-1667.

92 Zeder K, Avian A, Bachmaier G, et al. Exercise pulmonary resistances predict long-term survival in systemic sclerosis. Chest 2021; 159: 781-790.

93 Kovacs G, Maier R, Aberer E, et al. Pulmonary arterial hypertension therapy may be safe and effective in patients with systemic sclerosis and borderline pulmonary artery pressure. Arthritis Rheum 2012; 64: 1257-1262.

94 Saggar R, Khanna D, Shapiro S, et al. Effect of ambrisentan treatment on exercise-induced pulmonary hypertension in systemic sclerosis: a prospective single-center, open-label pilot study. Arthritis Rheum 2012; 64: 4072-4077.

95 Pan Z, Marra AM, Benjamin N, et al. Early treatment with ambrisentan of mildly elevated mean pulmonary arterial pressure associated with systemic sclerosis: a randomized, controlled, double-blind, parallel group study (EDITA study). Arthritis Res Ther 2019; 21: 217. Montani D, Lau EM, Dorfmüller P, et al. Pulmonary veno-occlusive disease. Eur Respir J 2016; 47: 1518-1534.

97 Montani D, Price LC, Dorfmuller P, et al. Pulmonary veno-occlusive disease. Eur Respir J 2009; 33: 189-200.

98 Eyries M, Montani D, Girerd B, et al. EIF2AK4 mutations cause pulmonary veno-occlusive disease, a recessive form of pulmonary hypertension. Nat Genet 2014; 46: 65-69.

99 Perros F, Günther S, Ranchoux B, et al. Mitomycin-induced pulmonary veno-occlusive disease: evidence from human disease and animal models. Circulation 2015; 132: 834-847.

100 Montani D, Lau EM, Descatha A, et al. Occupational exposure to organic solvents: a risk factor for pulmonary veno-occlusive disease. Eur Respir J 2015; 46: 1721-1731.

101 Johnson SR, Patsios D, Hwang DM, et al. Pulmonary veno-occlusive disease and scleroderma associated pulmonary hypertension. J Rheumatol 2006; 33: 2347-2350.

102 Pietra GG, Capron F, Stewart S, et al. Pathologic assessment of vasculopathies in pulmonary hypertension. J Am Coll Cardiol 2004; 16: S25-S32.

103 Lantuéjoul S, Sheppard MN, Corrin B, et al. Pulmonary veno-occlusive disease and pulmonary capillary hemangiomatosis: a clinicopathologic study of 35 cases. Am J Surg Pathol 2006; 30: 850-857.

104 Gupta S, Gupta A, Rehman S, et al. Pulmonary veno-occlusive disease is highly prevalent in scleroderma patients undergoing lung transplantation. ERJ Open Res 2019; 5: 00168-2018.

105 Holcomb B Jr, Lloyd J, Johnson E, et al. Pulmonary veno-occlusive disease: a case series and new observations. Chest 2000; 118: 1671-1679.

106 Montani D, Achouh L, Dorfmüller P, et al. Pulmonary veno-occlusive disease: clinical, functional, radiologic, and hemodynamic characteristics and outcome of 24 cases confirmed by histology. Medicine (Baltimore) 2008; 87: 220-233.

107 Hadinnapola C, Bleda M, Haimel M, et al. Phenotypic characterization of EIF2AK4 mutation carriers in a large cohort of patients diagnosed clinically with pulmonary arterial hypertension. Circulation 2017; 136: 2022-2033.

108 Bissell LA, Md Yusof MY, Buch MH. Primary myocardial disease in scleroderma - a comprehensive review of the literature to inform the UK Systemic Sclerosis Study Group cardiac working group. Rheumatol (Oxford) 2017; 56: 882-895.

109 Fernández-Codina A, Simeón-Aznar CP, Pinal-Fernandez I, et al. Cardiac involvement in systemic sclerosis: differences between clinical subsets and influence on survival. Rheumatol Int 2017; 37: 177.

110 Bulkley BH, Ridolfi RL, Salyer WR, et al. Myocardial lesions of progressive systemic sclerosis. A cause of cardiac dysfunction. Circulation 1976; 53: 483-490.

111 Mizuno R, Fujimoto S, Saito Y, et al. Cardiac Raynaud's phenomenon induced by cold provocation as a predictor of long-term left ventricular dysfunction and remodelling in systemic sclerosis: 7-year follow-up study. Eur J Heart Fail 2010; 12: 268-275.

112 De Luca G, Campochiaro C, De Santis M, et al. Systemic sclerosis myocarditis has unique clinical, histological and prognostic features: a comparative histological analysis. Rheumatol (Oxford) 2020; 59: 2523-2533.

113 Poindron V, Chatelus E, Canuet M, et al. T1 mapping cardiac magnetic resonance imaging frequently detects subclinical diffuse myocardial fibrosis in systemic sclerosis patients. Semin Arthritis Rheum 2020; 50: 128-134.

114 Ntusi NA, Piechnik SK, Francis JM, et al. Subclinical myocardial inflammation and diffuse fibrosis are common in systemic sclerosis - a clinical study using myocardial T1-mapping and extracellular volume quantification. J Cardiovasc Magn Reson 2014; 16: 21.

115 Tennøe AH, Murbræch K, Andreassen JC, et al. Left ventricular diastolic dysfunction predicts mortality in patients with systemic sclerosis. J Am Coll Cardiol 2018; 72: 1804-1813.

116 Allanore Y, Meune C, Vonk MC, et al. Prevalence and factors associated with left ventricular dysfunction in the EULAR Scleroderma Trial and Research group (EUSTAR) database of patients with systemic sclerosis. Ann Rheum Dis 2010; 69: 218-221. 
117 Guerra F, Stronati G, Fischietti C, et al. Global longitudinal strain measured by speckle tracking identifies subclinical heart involvement in patients with systemic sclerosis. Eur J Prev Cardiol 2018; 25: 1598-1606.

118 D'Alto M, Romeo E, Argiento P, et al. Hemodynamic changes after acute fluid loading in patients with systemic sclerosis without pulmonary hypertension. Pulm Circ 2019; 9: 2045894018816089.

119 Fox BD, Shimony A, Langleben D, et al. High prevalence of occult left heart disease in scleroderma-pulmonary hypertension. Eur Respir J 2013; 42: 1083-1091.

120 Robbins IM, Hemnes AR, Pugh ME, et al. High prevalence of occult pulmonary venous hypertension revealed by fluid challenge in pulmonary hypertension. Circ Heart Fail 2014; 7: 116-122.

121 Lammi MR, Saketkoo LA, Gordon JK, et al. Changes in hemodynamic classification over time are common in systemic sclerosis-associated pulmonary hypertension: insights from the PHAROS cohort. Pulm Circ 2018; 8: 2045893218757404.

122 Bonno EL, Viray MC, Jackson GR, et al. Modern right heart catheterization: beyond simple hemodynamics. Adv Pulm Hypertens 2020: 19: 6-15.

123 Rosenkranz S, Gibbs JSR, Wachter R, et al. Left ventricular heart failure and pulmonary hypertension. Eur Heart J 2016; 37: 942-954.

124 Bourji Kl, Kelemen BW, Mathai SC, et al. Poor survival in patients with scleroderma and pulmonary hypertension due to heart failure with preserved ejection fraction. Pulm Circ 2017; 7: 409-420.

125 Hoendermis ES, Liu LCY, Hummel YM, et al. Effects of sildenafil on invasive haemodynamics and exercise capacity in heart failure patients with preserved ejection fraction and pulmonary hypertension: a randomized controlled trial. Eur Heart J 2015; 36: 2565-2573.

126 Guazzi M, Vicenzi M, Arena R, et al. Pulmonary hypertension in heart failure with preserved ejection fraction: a target of phosphodiesterase-5 inhibition in a 1-year study. Circulation 2011; 124: 164-174.

127 Bonderman D, Ghio S, Felix SB, et al. Riociguat for patients with pulmonary hypertension caused by systolic left ventricular dysfunction: a phase $\mathrm{Ilb}$ double-blind, randomized, placebo-controlled, dose-ranging hemodynamic study. Circulation 2013; 128: 502-511.

128 Vachiéry J-L, Delcroix M, Al-Hiti H, et al. Macitentan in pulmonary hypertension due to left ventricular dysfunction. Eur Respir J 2018; 51: 1701886.

129 Young A, Vummidi D, Visovatti S, et al. Prevalence, treatment, and outcomes of coexistent pulmonary hypertension and interstitial lung disease in systemic sclerosis. Arthritis Rheumatol 2019; 71: 1339-1349.

130 Desai SR, Veeraraghavan S, Hansell DM, et al. CT features of lung disease in patients with systemic sclerosis: comparison with idiopathic pulmonary fibrosis and nonspecific interstitial pneumonia. Radiology 2004; 232: 560-567.

131 Okamoto M, Fujimoto K, Sadohara J, et al. A retrospective cohort study of outcome in systemic sclerosis-associated interstitial lung disease. Respir Investig 2016; 54: 445-453.

132 Daimon T, Johkoh T, Honda O, et al. Nonspecific interstitial pneumonia associated with collagen vascular disease: analysis of CT features to distinguish the various types. Intern Med 2009; 48: 753-761.

133 Jung $\mathrm{E}$, Suh $\mathrm{CH}$, Kim HA, et al. Clinical characteristics of systemic sclerosis with interstitial lung disease. Arch Rheumatol 2018; 33: 322-327.

134 Mayes MD, Lacey JV, Beebe-Dimmer J, et al. Prevalence, incidence, survival, and disease characteristics of systemic sclerosis in a large US population. Arthritis Rheum 2003; 48: 2246-2255.

135 Nihtyanova SI, Schreiber BE, Ong VH, et al. Prediction of pulmonary complications and long-term survival in systemic sclerosis. Arthritis Rheumatol 2014; 66: 1625-1635.

136 Asano $\mathrm{Y}, \mathrm{Ihn} \mathrm{H}$, Yamane $\mathrm{K}$, et al. The prevalence and clinical significance of anti-U1 RNA antibodies in patients with systemic sclerosis. J Invest Dermatol 2003; 120: 204-210.

137 Goh NSL, Desai SR, Veeraraghavan S, et al. Interstitial lung disease in systemic sclerosis a simple staging system. Am J Respir Crit Care Med 2008; 177: 1248-1254.

138 Chauvelot L, Gamondes D, Berthiller J, et al. Hemodynamic response to treatment and outcomes in pulmonary hypertension associated with interstitial lung disease versus pulmonary arterial hypertension in systemic sclerosis: data from a study identifying prognostic factors in pulmonary hypertension associated with interstitial lung disease. Arthritis Rheumatol 2021; 73: 295-304.

139 Launay D, Humbert M, Berezne A, et al. Clinical characteristics and survival in systemic sclerosis-related pulmonary hypertension associated with interstitial lung disease. Chest 2011; 140: 1016-1024.

140 Mathai SC, Hummers LK, Champion HC, et al. Survival in pulmonary hypertension associated with the scleroderma spectrum of diseases: impact of interstitial lung disease. Arthritis Rheum 2009; 60: 569-577.

141 Launay D, Montani D, Hassoun PM, et al. Clinical phenotypes and survival of precapillary pulmonary hypertension in systemic sclerosis. PLoS One 2018; 13: e0197112.

142 Antoniou KM, Margaritopoulos GA, Goh NS, et al. Combined pulmonary fibrosis and emphysema in scleroderma-related lung disease has a major confounding effect on lung physiology and screening for pulmonary hypertension. Arthritis Rheumatol 2016; 68: 1004-1012.

143 Cottin V, Nunes H, Brillet PY, et al. Combined pulmonary fibrosis and emphysema: a distinct under recognised entity. Eur Respir J 2005; 26: 586-593. 
144 Le Pavec J, Girgis RE, Lechtzin N, et al. Systemic sclerosis-related pulmonary hypertension associated with interstitial lung disease: Impact of pulmonary arterial hypertension therapies. Arthritis Rheum 2011; 63: 2456-2464.

145 Corte TJ, Keir GJ, Dimopoulos K, et al. Bosentan in pulmonary hypertension associated with fibrotic idiopathic interstitial pneumonia. Am J Respir Crit Care Med 2014; 190: 208-217.

146 Raghu G, Behr J, Brown KK, et al. Treatment of idiopathic pulmonary fibrosis with Ambrisentan: a parallel, randomized trial. Ann Intern Med 2013; 158: 641-649.

147 Nathan SD, Behr J, Collard HR, et al. Riociguat for idiopathic interstitial pneumonia-associated pulmonary hypertension (RISE-IIP): a randomised, placebo-controlled phase 2b study. Lancet Respir Med 2019; 7: 780-790.

148 Waxman A, Restrepo-Jaramillo R, Thenappan T, et al. Inhaled treprostinil in pulmonary hypertension due to interstitial lung disease. N Engl J Med 2021; 384: 325-334. 